The Compliance Cost of the Personal

Income Tax in India, 2000-01:

Preliminary Estimates

Arindam Das-Gupta 


\section{Contents}

Summary

1. Introduction and Outline 9

The Impact of Compliance Costs 9

Simplification and Compliance Cost 10

The Magnitude of Individual Compliance Costs
In other Countries

$\begin{array}{ll}\text { Outline } & 11\end{array}$

2. Measuring Compliance Costs: Conceptual Issues 12

Defining Costs of Tax Compliance 12

Mandatory and Voluntary Compliance Costs 13

Compliance Cost Components in this Study 13

Valuting Time and Tax Effects in Measuring
Compliance Costs

3. Problems with the Information Base and
Benchmarks for Compliance Costs

Sample Size and Universe Coverage 16

Why the Unreliable Study Findings are
Plausible Still worth Reporting

4 Compliance Cost of the Personal Income Tax

In India: Survey Findings 18

Basic Characteristics of Respondents 18

Use and Cost of Tax Advisors 18

Monetary Compliance Costs 19

Time Compliance Costs 20

Overall Legal Compliance Costs 21

Cost of Bribes and Harassment 22

Distribution of Compliance Costs across Gross
Income Groups and by Occupation

5. Aggregate Compliance Cost Estimates 25

The Cost of Deducting Taxes at Source: A Case Study 26

Costs of Collecting Taxes through the Public

Sector Banks 
Cost of Appeals, Litigation and Prosecution 27

Administrative Costs of Collecting Taxes 28

Aggregate Estimates $\quad 29$

6. Qualitative Information on Compliance Costs
of Inefficiency and Corruption

Bribes and Inefficiency in Relation to Refunds $\quad 30$

Other Comments on Bribes and Harassment $\quad 30$

Obtaining Permanent Account Numbers (PAN) 31

7. Conclusions 32

8. Reform Suggestions and Assessment of

Recommendations of the Direct Tax Task Force 33

Reforming Administration Institutions and Incentives $\quad 34$

Reforming Procedures $\quad 35$

Automation 36

Improving Monitoring, Reporting and Client Feedback 37

Reforming the Policy Process 38

$\begin{array}{ll}\text { Tables } & 41-55\end{array}$

Annex $\quad 56$

Methodology $\quad 56$

Areas Covered in Questionnaires $\quad 58$

Sample Versus Population Distributions $\quad 58$

$\begin{array}{ll}\text { Aggregation Methodology } & 61\end{array}$

Individual Income Tax, Surcharge and

Standard Deduction Rates: 1990-00 and 2000-01 62

Income Tax Knowledge of Respondents 63

Distribution of Compliance costs in the Sample $\quad 64$

$\begin{array}{ll}\text { References } & 67\end{array}$ 


\section{Summary}

Simplification and Compliance Costs: Complexity of the tax system possibly has adverse effects on tax administration, compliance and compliance costs. Complexity is caused by complex tax laws or administrative procedures, discretionary provisions, tax concessions and poorly drafted laws. A number of countries have attempted tax simplification to reduce compliance and administrative costs.

Compliance Costs in Developed Countries: These vary between 3.91 percent of tax revenue in the UK in 1986-87 to between 7.9 to 10.8 percent in Australia in the 1990s.

Defining Compliance Costs: Compliance costs are incurred by taxpayers but also third parties who collect taxes (e.g. tax withholders) or who are required to provide information to the tax administration. Nonfilers incur costs of non-compliance. So tax compliance cost elements included, in principle, in this study are all costs incurred by taxpayers, non-filers and third parties to comply with tax obligations. Tax compliance costs can be voluntary or mandatory, though both add to the social cost of the tax. Bribes, being a transfer are part of private costs but not costs to society. Compliance activity also has benefits via better record keeping or cash flow benefits of tax deductors. Costs arising from economic distortions and equity violations are, however, omitted.

Information base, sample size and response rate: Besides primary survey data and case studies, relevant secondary data are used. For the survey, from a list of 10,234 names the eventual response rate was a disappointing 2.36 percent amounting to less than one taxpayer per 100,000 income tax payers in 2000-01. Overall, the final sample of 172 taxpayers is biased towards high income respondents and salary earners. Therefore, findings of this study must be taken as very preliminary and subject to a large error margin. Nevertheless, the high compliance costs documented make it clear that a reliable cost assessment is urgently needed. 


\section{Estimates of Compliance Costs:}

- Estimates of compliance costs are high by international standards even for salary earners and excessive for non-salaried taxpayers equalling, at the median, 130 percent of taxes paid.

- Costs are regressive and, for low income and middle income nonsalary earners, can be more than double taxes paid even if bribe costs are neglected.

- Both the incidence of bribe payment and the bribe quantum are high, even among salary earners, but especially so for non-salary earners.

- Harassment of assessees in various forms, whether related to bribes or not, is a serious problem.

- Overall, despite the personal income tax being limited to only around 20 million taxpayers, costs directly borne by taxpayers are estimated at over 0.8 percent of GDP or 49 percent of personal income tax collections. With third party compliance costs, this rises to 56 percent of taxes collected. If conservatively "guesstimated" non-filer costs are added, costs further increase to 59 percent of tax revenue. The overall social cost of the personal income tax, adding administration costs and subtracting bribes is 60 percent of tax revenue. It is reiterated that the poor information base implies that these estimates are subject to a wide margin of error.

\section{Other Findings of Interest:}

- Advisor's are used more to deal with tax uncertainty and administrative procedures than to help in reducing tax burdens through tax planning.

- Third party costs of deducting tax at source amounted, in a case study, to 11.8 percent of taxes withheld.

- Commercial bank costs of receiving and remitting taxes, over and above reimbursement received from the government, were Rs. 363 crore or about 1 percent of tax collections.

- Long delays in receipt of PAN cards and numbers are a source of harassment.

- Appeals, due to their long duration and the fact that the IT Department has been alleged to lose most appeals, lead to 
avoidable cost to both taxpayers and government. One reason for extensive appeals is the fear of not achieving internal targets by assessing officers, leading to unsustainable, "high pitched assessments".

- Delayed refunds are a cause of harassment and associated with forced bribe payments by salary earners.

- Clearances and permissions required from tax authorities have, according to tax professionals, similar characteristics.

- While findings are not conclusive on the impact of avoidance activity on compliance costs, results, if anything, suggest no uniform impact of avoidance on compliance costs.

Some reform suggestions: A six-pronged approach to reducing the operating cost of the personal income tax is first suggested: Tax structure simplification, institutional reform, procedural reform, automation, monitoring and client feedback, and tax policy process reform. If this proves to have an inadequate impact on compliance costs, then drastic tax reform is worth considering seriously. 


\title{
The Compliance Cost of the Personal Income Tax in India, 2000-01: Preliminary Estimates*
}

\author{
Arindam Das-Gupta**
}

\section{Introduction and Outline}

\section{The Impact of Compliance Costs}

Taxpayer compliance costs are an area of growing concern and, for example, have found their way even into political platforms in countries like Australia and the United Kingdom. ${ }^{1}$ Compliance cost have been explicitly addressed in the policies of countries like the USA, Australia, the UK, the Netherlands and New Zealand ${ }^{2}$ and, increasingly, in India. In the UK, compliance cost assessments (CCAs) are now mandatory while introducing new tax proposals. ${ }^{3}$ In Australia, any change in taxation legislation is supported by Taxation Impact Statements (TIS), which details the impact on taxpayers of the legislation and include an assessment of compliance costs. Formal estimation of the overall compliance burden of the tax system was first attempted by Haig (1935)

If the terminology and interest in compliance costs are of recent origin, the ideas are old. In fact, three out of four of Adam Smith's canons

\footnotetext{
* This paper is excerpted and condensed from a report on company compliance costs, Chattopadhyaya and Das-Gupta (2002), prepared for the Planning Commission at the National Institute of Public Finance and Policy. The report is available at the Planning Commission website http://www.planingcommission.nic.in/reports.

** Professor of Economics and Finance, Goa Institute of Management, Ribander, Goa 403006, India. Phone: 91-832-2444638, E-mail: oldmonk87@yahoo.com.

1 See, Evans and Walpole (1997).

2 See, Sandford (1995).

3 See, for example, Sandford (1995). Such CCAs are based on estimated compliance costs of a 'typical' business.
} 
of taxation relate directly or indirectly to tax compliance costs. They are 'Certainty', 'Convenience', and the 'Economy', the other being 'Equity'. Economic effects of high compliance costs include deadweight resource costs, increased non-compliance, distorted production decisions and reduced investment, higher deficits, reduced tax equity, lower economic growth and adverse price movements. Compliance costs, by increasing the effective marginal tax rate, may also distort and hinder investment decisions, both domestic and foreign.

\section{Simplification and Compliance Costs}

Growing complexity of the tax system has adverse effects on tax administration, compliance and compliance costs (Sandford, 1995; Bardsley, 1997). Much discussion of simplification reflects a misunderstanding of what makes a tax system complex. For instance, the very use of the income tax rather than a sales tax increases the complexity of tax laws, increasing compliance costs. ${ }^{5}$ Tax simplification is necessary but not sufficient to help reduce taxpayers' costs of compliance (James, Sawyer, and Wallschutzky, 1997). In the US, simplification was one of the main objectives of the tax reform movement of the 1980s that culminated in the tax reform act of 1986. Comparing surveys of compliance cost in 1982 and 1989, Blumenthal and Slemrod (1992) concluded that tax reform did not reverse the growth in compliance costs in the 1980s. In other countries simplification during 1980s has also been found to increase compliance costs except in one study of Sweden (Malmer, 1995). ${ }^{6}$

\section{The Magnitude of Individual Compliance Costs in other} Countries

\footnotetext{
4 'Certainty' implies that tax liabilities should be clear and certain, rather than arbitrary; 'Convenience' of payment of taxes refers to the collection of taxes, which should be done in a manner and at a time convenient to the taxpayer; and 'Economy' in collection means that it should not be expensive to collect taxes and hence discouraging for business.

5 See, Kaplow (1995).

${ }^{6}$ See, also McClure (1989), Boucher (1991), Pope (1994), Talib (1996), Bardsley (1996) and James, Sawyer and Wallschutzky (1997).
} 
Based on large-scale surveys, Sandford estimates the compliance costs of UK tax system in 1986-87 at 3.91 percent of the tax revenue. In terms of percentage of GDP, "compliance costs emerge as in excess of 1 percent of GDP" (Sandford, 1989). In recent estimates of compliance costs of US individual income tax "the annual compliance costs of the federal and sub-federal individual income taxes is many times higher than the budget of the tax administration agency, being $\$ 35$ billion compared to the total IRS budget of about $\$ 6$ billion" (Blumenthal and Slemrod, 1996). In Table 1 an international comparison of compliance costs estimates for developed countries is presented. ${ }^{7}$ No information is available on income tax compliance costs in India. ${ }^{8}$

\section{Outline}

In section 2, compliance costs are defined and the coverage of compliance costs in this study is described. Section 3 is an important section of the paper and describes the severe weaknesses in the information base of the study. In the section arguments are also presented as to why, nonetheless, the study is important for current policy. In section 4, sample based estimates of compliance costs of the personal income tax in India, which are extraordinarily high by international standards, are presented. Using sample based information as well as secondary data on certain types of compliance costs which cannot be assessed using the sample, aggregate estimates are presented in section 5 . In section 6 qualitative information on compliance costs is presented, in an attempt to bring home the human dimension of the statistics presented in the earlier two sections. Section 7 reviews the main conclusions. In section 8, some suggestions for compliance cost lowering reforms of tax administration are made along with an assessment of recommendations on the same or related issues by the recently concluded Direct Tax Task Force (2002).

7 Estimates of compliance costs are not strictly comparable due to very different tax systems and serious differences in methods adopted. A full review of earlier compliance cost studies, almost all for developed countries, is in Chattopadhyay and Das-Gupta (2002).

8 Mrs R. Rajamani of the Indian Revenue Service confirmed that she had carried out such a study in the late 1990s but expressed her inability to share the study. Two earlier studies on Indian tax compliance costs, but not for the income tax, are discussed in Chattopadhyay and Das-Gupta (2002). 


\section{Measuring Compliance Costs: Conceptual Issues}

\section{Defining Costs of Tax Compliance}

The conventional definition of tax compliance costs, for example in Sandford (1995) is:

"Tax compliance costs are the costs incurred by the taxpayers in meeting the requirements laid on them by the tax law and the revenue authorities. They are costs over and above the actual payment of tax and over and above any distortion costs inherent in the nature of the tax."

Compliance costs are not only incurred by taxpayers but by all agents involved in facilitating the transfer from the private sector to the government exchequer. For example, employers responsible for tax deduction at source and financial institutions entrusted with collecting taxes also incur compliance costs. Overall costs of a tax system include "welfare costs, opportunity costs, psychic costs, social costs and so on". To assess the total impact of taxes on society, "the total sacrifice imposed upon the populace - total collection costs, administrative and compliance costs, should be looked into". ${ }^{10}$ Slemrod and Yitzhaki (1996) identify compliance costs as one of the five component costs of taxation. The others are administrative costs, deadweight efficiency loss from taxation, the excess burden of tax evasion and avoidance costs.

Sandford et. al. (1989) have emphasised the need to include psychic costs of complying with taxes, in particular for the poorer pensioners, widows and single women. So far, practical methods for measuring these costs have proved elusive. ${ }^{11}$

9 See, Evans and Walpole (1997).

${ }_{11}^{10}$ See, Mikesell (1986).

11 Chattopadhyay and Das-Gupta (2002 and 2002a) discuss attempts made by them to measure the psychic costs of tax policy uncertainty and tax law ambiguity and complexity by using contingent valuation methods. Though responses of those who 


\section{Mandatory and Voluntary Compliance Costs}

Compliance costs can be classified as mandatory and voluntary, with the latter being closely related to the Slemrod-Yitzhaki category of avoidance costs. ${ }^{12}$ For policy the two types of costs have different implications. While the government can directly affect the former by simplification, the latter is affected by several social factors, such as fiscal attitudes of the society, and uncertainty, which the government cannot easily influence. In view of different policy prescriptions involved, the distinction between the two needs to be made clearly, to the extent possible.

\section{Compliance Cost Components in this Study}

Given the discussion above, it will be clear that definition and classification of compliance costs is not a simple task. In defining the compliance costs of taxation to society as a whole, we include, in this study, all costs due to the tax system borne by taxpayers and third parties other than cost arising from economic distortions and equity violations. We include, therefore, costs of both compliance and noncompliance, combining compliance costs and avoidance costs in the Slemrod-Yitzhaki classification. Components of the social cost of tax collection, including compliance costs, included and excluded in this study are summarised in tabular form at the end of this section. The table makes clear that the study underestimates the compliance costs of the income tax.

\section{Valuing Time and Tax Effects in Measuring Compliance Costs}

If labour hours are perfectly flexible, then the standard neoclassical labour-leisure choice model with competitive labour markets requires that compliance time be valued at the after tax wage rate, using

appeared to understand what was being asked revealed a high correlation between objective and psychic compliance costs, the attempt was not very successful given the low response rate to contingent valuation questions, even relative to other areas in this survey and the large number of zero responses to the questions.

${ }^{12}$ See, Johnston (1961) and Sandford (1965). 
the individual's marginal tax rate. Lost work hours should, in contrast, be valued at the gross wage rate with competitive labour markets. In the absence of competition, a shadow wage rate should be used. In the absence of perfect flexibility, the valuation, even by the individual, depends on the extent to which compliance time reduces paid work time, valued at the gross wage, and the extent to which it reduces leisure, to be valued at the post tax wage. This valuation ignores possible psychic costs because, say, individuals prefer working to compliance activity. ${ }^{13} \mathrm{~A}$ third possibility is that compliance time supplants work time, which, due to imperfect supervision, does not reduce the taxpayer's earnings. In this case, the value of time spent is zero to the taxpayer aside from psychic costs, while the value to society is still the gross wage. In the presence of tax evasion and avoidance, effective marginal tax rates should be used. Under the assumption that private and social costs coincide, one way out is to elicit the compensating variation for compliance time directly from the individual. This was attempted unsuccessfully by Slemrod and Nikki Sorum (1984) and also, apparently successfully, by Bhatnagar (1997). In this study, both the average wage and the individual's own time valuation (both either in pre-tax or post-tax terms depending on the individuals alternate use of time) are used in measuring compliance costs, though final estimates reported are deliberately biased downward by taking the minimum of these.

\section{Personal Income Compliance Cost Components Included in The Study}

\footnotetext{
${ }^{13}$ Slemrod and Sorum (1984).
} 
A. Tax Compliance Costs

\begin{tabular}{|c|c|c|c|c|c|}
\hline Category & $\begin{array}{l}\text { Individual } \\
\text { taxpayers } \\
\text { (salaried) }\end{array}$ & $\begin{array}{c}\text { Individual } \\
\text { taxpayers } \\
\text { (non- } \\
\text { salaried) }\end{array}$ & $\begin{array}{l}\text { Non- } \\
\text { filers }^{14}\end{array}$ & $\begin{array}{l}\text { Third parties } \\
\text { (banks, tax } \\
\text { withholders, } \\
\text { employers ) }\end{array}$ & $\begin{array}{l}\text { Third parties } \\
\text { (others) }\end{array}$ \\
\hline $\begin{array}{l}\text { Time spent by } \\
\text { individual }\end{array}$ & Yes & Yes & No & NR & $\begin{array}{l}\text { Yes (Time } \\
\text { spent } \\
\text { helping } \\
\text { others } \\
\text { comply) }\end{array}$ \\
\hline $\begin{array}{l}\text { of which on Tax } \\
\text { Planning }\end{array}$ & Yes & Yes & NR & NR & NR \\
\hline $\begin{array}{l}\text { Direct money costs } \\
\text { (including fees paid } \\
\text { to tax professionals) }\end{array}$ & Yes & & No & Yes $^{*}$ & No \\
\hline $\begin{array}{l}\text { of which on Tax } \\
\text { Planning }\end{array}$ & Yes & Yes & NA & $\mathrm{No}^{* *}$ & NA \\
\hline $\begin{array}{l}\text { of which employee } \\
\text { costs }\end{array}$ & NR & Yes & No & Yes* & No \\
\hline Bribes paid & Yes & Yes & No & No & No \\
\hline Psychic costs & $\begin{array}{l}\text { Not } \\
\text { reported }\end{array}$ & $\begin{array}{l}\text { Not } \\
\text { reported }\end{array}$ & No & No & No \\
\hline $\begin{array}{l}\text { Benefits from } \\
\text { compliance } \\
\text { requirements }\end{array}$ & No & Yes & NR & No & No \\
\hline \multicolumn{6}{|c|}{$\begin{array}{l}\text { C. Other social costs of the personal income tax - not examined in detail } \\
\text { Budgetary costs of the income tax department in relation to the personal income tax. } \\
\text { Budgetary costs of the rest of government (courts, police, legislators, CAG, law } \\
\text { ministry, etc). } \\
\text { Economic efficiency costs of the personal income tax. } \\
\text { Economic efficiency costs of personal income tax evasion. }\end{array}$} \\
\hline \multicolumn{6}{|c|}{$\begin{array}{l}\text { Notes: } \\
{ }_{*} \text { Case studies only. } \\
{ }_{* *} \text { For example, cost of tax compliance by company accountants on behalf of } \\
\text { employees and directors. } \\
\text { NR: Not relevant. }\end{array}$} \\
\hline
\end{tabular}

NR: Not relevant.

\section{Problems with the Information Base and Benchmarks for Compliance Costs}

\footnotetext{
14 These costs are examined by Chattopadhyay and Das-Gupta (2002b) and the estimate of these costs from there is included in the aggregate compliance cost estimates presented below.
} 


\section{Sample Size and Universe Coverage}

Sample size: In brief, 10,234 randomly selected addresses individuals were obtained from a government data base which covered a large percentage of income tax assessees. The ultimate sample size from mailed and canvassed questionnaires was disappointing, at 122 salaried and 50 non-salaried respondents. Questionnaire design, sample design and response rates, and methodology are described in the Annex. ${ }^{15}$

Universe Coverage: According to the report on direct taxes of the CAG (2001), the number of income tax assessees stood at 1,95,67,937 in 1999-2000. This implies a sample coverage of 0.00089 percent or just under one taxpayer per lakh $(1,00,000)$ of assessees. Overall, the sample is biased towards high income respondents, salary earners, and possibly, the highly educated. Sample characteristics in comparison to population characteristics are presented in the Annex .

\section{Why the Unreliable Study Findings are Plausible Still Worth Reporting}

Given the small study sample, it is best viewed as no more than case studies of 172 individual income tax assessees. Samples are inadequate for reliable statistical inference due to the very low response rate, often curtailed further by incomplete questionnaires. There is, therefore, no doubt that average results are subject to a wide error margin. Strong reservations have been expressed about the value of aggregate compliance cost estimates compiled on the basis of such shaky data. ${ }^{16}$ Furthermore, methods used to value time expended on

${ }^{15}$ Full discussion is in Chattopadhyay and Das-Gupta (2002) which also has an evaluation of the mailed, anonymous, questionnaire method adopted for this study against the alternative of canvassed surveys as well as suggestions for future studies.

16 By Professor D.K. Srivastava. While agreeing with him the justification for presenting aggregate estimates is that in their absence no comparison of survey based compliance costs items and other compliance cost items compiled using indirect information could be made. 
compliance activities, though standard in the literature, have been questioned in the Indian context. ${ }^{17}$

While accepting the possible validity of these criticisms, the results are still felt to be worth reporting: Even the median salary earner in these "case studies" had a compliance cost in excess of the highest figure in Table 1, while the outrageous compliance costs of almost all non-salaried individuals in the sample clearly calls into question the very rationale of the personal income tax - even if they are all outliers (See Appendix Tables A10 to A12). Indeed, for many "case studies", monetary cost alone exceeds total compliance costs in earlier studies.

In the event that findings of this study cannot be refuted by a more satisfactory study with an adequate sample, then no government in the world has the right to burden its citizens with such a costly source of finance for government expenditure. ${ }^{18}$ Compliance costs should either be lowered or high compliance cost groups - which may include the majority of taxpayers - should be exempted from the personal income tax. It is, therefore important that the results from the first publicly available study of personal income tax compliance costs be made available to scholars to examine and, hopefully, refute when superior information becomes available.

\section{Compliance Cost of the Personal Income Tax in India: Survey Findings}

\footnotetext{
${ }^{17}$ By Professor Amaresh Bagchi. While the author does not find his arguments persuasive (that the opportunity cost of time spent complying has little to do with hourly wage rates should, nonetheless, be noted.

18 Professor Richard Bird commented on a draft of Chattopadhyay and Das-Gupta (2002): "First, in substantive terms, this report is perhaps the strongest evidence I have ever seen suggesting that the PIT [Personal Income Tax] in India is a complete waste of time and money. The country (and the government) would, it seems, be significantly better off if the thing were simply abolished."
} 


\section{Basic Characteristics of Respondents}

The method of estimating different tax and income variables used in this study is described in detail in Chattopadhyay and Das-Gupta (2002). Information on incomes and tax payments of respondents is in Table 2. The mean sample income is around 79 percent above the estimated mean population income. Correspondingly, income tax payments are more than double the population average. One unexpected finding is the large TDS percentage of non-salary earners, presumably for interest and dividend income.

Information on taxpayers under scrutiny (or tax audit by the Income tax Department) is in Table 3. Given respondents' high income levels, the percentage under scrutiny was larger than the 1 percent to 2 percent of taxpayers scrutinised annually by the Income tax Department in recent years. ${ }^{19}$ Furthermore, a remarkable 22 percent of non-salaried taxpayers and 13 percent of all taxpayers had ongoing scrutiny proceedings with attendant expenditure of time or money. The possibility that Income-tax department scrutinies contribute substantially to compliance costs both in terms of the number of taxpayers affected and in terms of compliance costs per taxpayer is confirmed by Chattopadhyay and Das-Gupta (2002) who find, using regression analysis, that the extra compliance cost of scrutinised individuals, controlling for other factors, amounts to 34 percent of tax paid.

\section{Use and Cost of Tax Advisors}

Reliance on tax practitioners was much higher among the selfemployed, while fully a third of salary earners completed their own tax returns (Table 4).

Correspondingly, more salaried taxpayers helped others with their tax returns (incurring "third party compliance costs") and spent larger amounts of time doing so than the non-salaried (Table 5). Using a conservative value for the opportunity cost of time, discussed below,

${ }^{19}$ According to the CAG (2001), for both personal income and corporation tax combined, $1.15 \%$ of the 2.74 crore assessments due for disposal in $1999-2000$ were subjected to scrutiny. 
third party costs of unpaid assistance from friends to help others comply can be valued at Rs. 399 per salaried taxpayer and Rs. 405 per nonsalaried taxpayer given the higher value of time of the latter.

Table 6 shows that both use of tax advisors and fees paid to them were higher for the non-salaried. Reported fees paid in Table 6 correspond reasonably well with those from a case study of a firm of Chartered Accountants, which charges salary earners Rs. 500 to Rs. 1000 and non-salary earners Rs. 1000 to Rs. 5000 .

Reasons for use of tax advisors appear to differ between salaried and non-salaried respondents, though very few salaried responses were available (Table 7). Tax uncertainty due to frequent changes in tax provisions and, correspondingly, the desire to ensure perfectly prepared tax documents were considered most important by salary earners. Tax planning was the most important reason for use of tax advisors by the non-salaried, though, overall, they did not give great weight to any one reason.

In a focus group meeting with members of the Bombay Chartered Accountants Society, a tax professional expressed the opinion that among major reasons that taxpayers used professional advisors was because outsourcing was generally cheaper and, secondly, for representation before tax authorities in the even of scrutiny or other postassessment proceedings.

\section{Monetary Compliance Costs}

Monetary compliance costs of respondents are reported in Table 8. Even if time compliance costs are totally omitted, average monetary compliance costs as a percentage of tax are large relative to total compliance costs of the income tax found internationally which are reported in Table 1. This is the case even if conservative sample medians figures are used for comparison. Monetary costs for the nonsalaried are especially high as a percentage of taxes and income in comparison with compliance costs in other countries.

Regarding different components (Table 9), record keeping costs and advisor's fees form the bulk of costs of non-salaried individuals while advisors fees and tax planning costs dominate for salary earners. The

importance of these costs parallels findings for other countries as 
reported, for example, by Walpole, et. al. (1999). However, even for the average salaried taxpayer average monetary costs exceed average total compliance costs found in compliance cost studies conducted in other countries.

\section{Time Compliance Costs}

On average, non-salaried taxpayers spent 88 hours per year complying with tax obligations of which the bulk of time was spent keeping records (Table 10). In contrast salary earners spent 28 hours complying with tax obligations. These averages are high relative to what is seen internationally. However, sample medians at 11 hours and 30 minutes for the salaried and 17 hours for the non-salaried (Table A10 in the Annex) are comparable to figures reported internationally raising the possibility that the averages do not reflect the experience of the representative taxpayer. For comparison, 11 hours and 27 hours respectively were spent per taxpayer in New Zealand and the United States (Hite and Sawyer, 1997), and 11.2 hours were spent per household per year in Germany (Tiebel, 1984 as reported by Fischer, 1989).

Turning to components, salary earners spent nearly 30 percent of the time or around 9 hours in tax planning, the rest being spent on mandatory compliance activities. Because of greater reliance on tax advisors, self-employed taxpayers spent less time (6-7 hours) on tax planning.

In putting a monetary value to these time compliance costs, four potential values of the opportunity cost of time were computed:

- The self-assessed value per hour of the respondent if respondent stated that (s)he would spend an hour saved from time compliance activities to earn more.

- The respondent's self-assessed value per hour multiplied by (1 minus the respondents marginal tax rate) if the respondent stated that (s)he would spend an hour saved from time compliance activities on leisure activities.

- The average pre- or post-tax hourly earnings of the respondent assuming 1920 working hours per year. 
The least of these values (which obviously excluded the pre-tax wage) was then taken, to get the "conservative value of time per hour". ${ }^{20}$ A summary of these figures is in Table 11. This procedure obviously biases estimates downward. ${ }^{21}$ Nevertheless, even at conservative values, time compliance costs are extremely high on average (Table 12). These costs are estimated at Rs. 27,000 per annum for non-salaried taxpayers and Rs. 2,100 for salaried taxpayers. However, median values, though high are much more conservative at below Rs 1,500 and 900 respectively, though as a percentage of tax even these are high by international standards. That median figures in hours are reasonable internationally but those in rupees are not, is partly a reflection of the high income bias in the sample, which gets further accentuated by the 55 individuals whose compliance costs are more than 25 percent above the median (see Table A11). Of different components, record-keeping by non-salary earners appears to be most burdensome (Table 13). ${ }^{22}$

\section{Overall Legal Compliance Costs}

These are reported in Table 14 and, for the tax planning cost component, in Table 15. The picture emerging from the table is of a high compliance cost tax system, with costs largely being associated with compliance activities considered mandatory by taxpayers which yield no offsetting tax benefits. This is particularly true for the non-salaried, whose costs are, on average 10 times higher than salaried taxpayers. Nevertheless, even median costs as a percentage of taxes paid by salary earners are high by international standards. Since the data base of the study is small and far from ideal, it is worth reiterating that the results should be treated with caution. Nevertheless, subject to further study, the desirability of a high cost tax such as the personal income tax in India is clearly called into question.

${ }^{20}$ The correlation between the average wage and the self assessed value is 0.678 while the correlation between the average wage and the conservative value is 0.868 . A regression of the average wage on self assessed value has the equation: average wage $=0.0605+0.118$ (self assessed value), with an R-squared of 0.46 .

${ }^{21}$ For example, the ratio of time costs to monetary costs is below that in many international studies. See, for example, Sandford, Godwin and Hardwick (1989).

22 In the literature, a known possible source of bias in figures for record-keeping as in Table 11 is if the self-employed include ALL record-keeping time in their estimates and not just time for tax purposes. However, in the canvassed pre-survey where this problem was guarded against, reports by some pre-survey respondents are higher than in the final survey, though means are not significantly different, statistically. 
A view sometimes expressed is that tax concessions are provided for socially desirable activities or uses of income that are substitutes for direct government expenditure. If this is accepted, only a part of compliance costs are for raising revenue, the rest being the cost of getting benefits from transfers or tax expenditures. So a modified measure is required to assess the compliance cost of raising revenue. This is the ratio of compliance costs to gross taxes. This ratio, along with taxes saved as a percentage of gross taxes is therefore presented in Table 16. As can be seen, compliance costs are substantial even by this yardstick, in excess of 100 percent for the non-salaried. Of interest is the remarkably close figures for tax saving as a percentage of gross taxes for both salaried and non-salaried (43 percent to 45 percent) and the low coefficient of variation. Nevertheless, medians differ widely, with the median non-salaried respondent having no tax saving implying skewed tax saving behaviour by them. Overall, the conclusion appears warranted (subject to caveats regarding the data) that generous concessions raise compliance costs of tax payers while ending up narrowing the tax base and reducing tax buoyancy.

A final way of viewing the impact of compliance costs is to add compliance costs as a percentage of gross income to the effective income tax rate. This is done in Table 17. As can be seen, the increase in the tax burden of non-salaried respondents is more than two-thirds, while that of salaried taxpayers is around 26 percent.

However, for the non-salaried taxpayer there are offsetting benefits, chiefly in terms of preparing income statements (6 respondents) and also from better asset and inventory management ( 3 respondents each) Unfortunately only 8 qualitative responses on benefits are available.

\section{Cost of Bribes and Harassment}

Of survey respondents, 23 percent of salary earners and 42 percent of non-salaried respondents in the final survey "admitted" to paying bribes, keeping in view that respondents were asked if similar 
persons paid bribes rather than if they themselves paid bribes. ${ }^{23}$ Since "no comment" and omitted responses are also from potential bribe payers, the number of potential bribe payers rises to 59 percent for salary earners and 79 percent for non-salaried respondents.

To ascertain the quantum of bribes respondents were offered the choice of stating bribe amounts in rupees, as a percentage of taxes paid or as a percentage of taxes saved (Table 18). If the bribe was reported as a percentage of tax saved, it is assumed that the rupee value of the bribe was equal to the percentage difference between our estimate of tax and tax reported by the respondent, if the former exceeded the latter. Otherwise, the information was treated as missing. Eight salary earners who responded to this question, reported bribes at between 5 percent and 20 percent of tax saved, with a median value of 10 percent $^{24}$ The four non-salary respondents to this question reported that bribes were 50 percent, 20 percent and 10 percent of taxes saved, respectively. A fourth reported bribes at 100 percent of taxes paid. ${ }^{25}$ If per taxpayer bribe payments are realistic, which may be a big if, the table shows that bribe costs are substantial even for salaried respondents. For non-salaried respondents, bribe costs of those paying bribes exceeded average legal compliance costs.

Though Table 19 presents survey information from questions regarding harassment, these should not be added to bribe costs, to avoid possible double counting. The important point made by the table is that harassment by income tax officials is not uncommon, especially for salaried taxpayers. While no attempt has been made to go beyond the quantification of harassment costs by the respondents themselves, clearly, harassment adds substantially to compliance costs of the individual income tax in India if sample responses are found to be capable of replication.

23 The maximum bribe paid figure of $\mathrm{Rs} 1,47,557$ was from a pre-test canvassed questionnaire, where the respondent was asked directly about his bribe payments.

${ }^{24}$ As discussed later, several qualitative responses by salary earners indicated that bribe payments were to obtain refunds, often through advisors. The going rate for such bribes was reported at $10 \%$ of the refund due.

${ }^{25}$ This was a book-shop owner with a reported income of Rs 27 lakh who claimed that all book-shop owners had to annually pay large bribes under the threat of revaluation of old stocks and consequent loss 
Bearing in mind the indirect nature of questions to elicit information on bribe payment behaviour, it is still of interest to examine aggregate compliance costs, including bribes. Under the assumption that those not responding to bribe questions in the survey did not pay bribes, Table 20, when compared to Table 18 suggests that the average bribe cost for salaried taxpayers is around Rs. 200, while that of the nonsalaried is around Rs. 4,000. The corresponding figures at the median are much lower, at Rs 2 and Rs 500.

\section{Distribution of Compliance Costs across Gross Income Groups and by Occupation}

Tables 22 and 23 along with Figure 1, provide information on variation of compliance costs with income. Overall, compliance costs as a percentage of income have an inverted U-shaped pattern of incidence, first rising then falling with increasing income, for both salaried and nonsalaried taxpayers. This pattern is opposite to that reported in Slemrod and Blumenthal (1989) for US taxpayers. Therefore, while increasing the progressivity of the income tax below Rs. 200,000, they add a regressive bias above this. Note that compliance costs, in some cases, even for legal compliance costs of salary earners, exceed tax paid. 


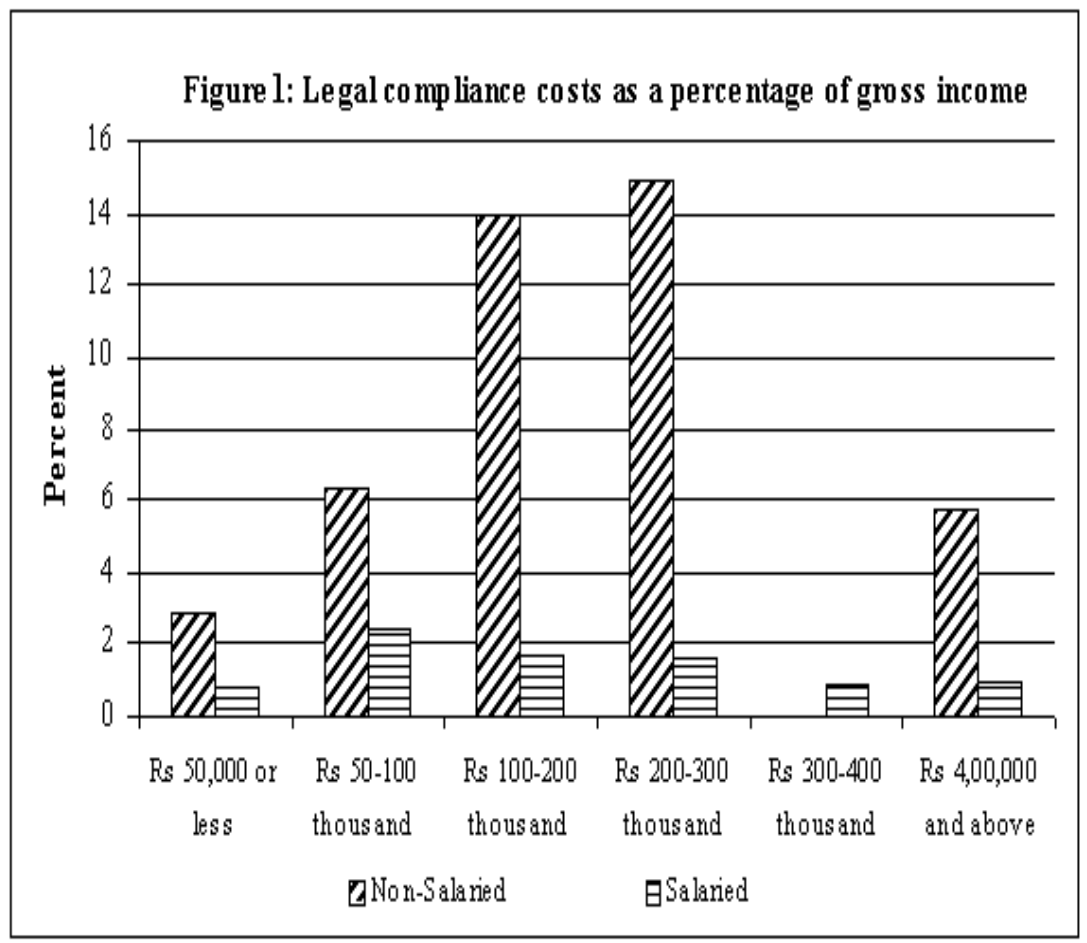

Despite data limitations, an examination of indices of the progressivity of compliance costs is reported in Table 23. The table shows that, overall, compliance costs are regressive increasing the inequality of income, especially if bribe costs are taken into account.

\section{Aggregate Compliance Cost Estimates}

The justification for the aggregate estimates given here, it is recalled, is solely to provide a basis for comparison with compliance cost components, such as third party costs, which are not measured via the survey. To do so, however, sample data by income range must be reweighted so that the average cost is for the population distribution of taxpayers rather than the sample distribution. That these figures are 
subject to a wide error margin should be obvious. Before presenting aggregates based on sample based figures, estimates of some missing compliance cost elements in the survey are first presented. These pertain to litigation costs, third party costs of tax withholders and banks, and costs of non-filers. An estimate of the cost of administering the income tax is also made, so that the total cost of collecting the income tax (excluding efficiency and equity costs) can be examined. Of these costs, compliance cost of non-filers are "guesstimated" by Chattopadhyay and Das-Gupta (2002b) to be around Rs. 1089 crore or 3.4 percent of personal income tax collections for the year.

\section{The Cost of Deducting Taxes at Source: A Case Study}

The cost of deducting income taxes at source (TDS) is an important part of third party compliance costs. Collections through TDS constituted 53 percent of total collection of income taxes and 60 percent of non-company income taxes in 1999-2000 (CAG 2001). An important reason for the low compliance costs of salaried individuals is because their employers bear the costs of assessing their tax liabilities and preparation tax deduction statements (Form 16A) for employees. The following case study is indicative.

Three types of compliance costs of TDS were identified: $(A)$ external costs including fees paid to an external Chartered Accountant, (B) staff costs and (C) overhead administrative expenses. Staff costs are accounts department costs of to completing and submitting TDS returns, depositing TDS and time spent by them to complete and submit Form 16A for employees. Overhead expenses include computer costs for TDS returns and form 16A, photocopying, postal and fax expenses, travel and conveyance, prorated office space at the market rental value, general supplies, stationery and consumables, maintenance and purchase of tax publications and journals. These are listed in Table $24{ }^{26}$

\footnotetext{
${ }^{26}$ The organisation paid Rs. 3000 to a tax advisor. The accounts department has a staff of 6 with combined daily salary amounting to Rs. 583, assuming 20 working days per month. Given 70 income tax assessees in the organisation, the total time spent was 2.1875 days a month implying staff costs of Rs. 1,276 per annum. Total computer costs of the accounts department was Rs. 80,056 per annum of which TDS related usage was estimated at 30 days of 240 working days in a year. Rs. 120,000 or one percent of the estimated annual rental value of office space of the organisation (Rs. 12,000,000) was conservatively taken as the share of the Accounts Department of which Rs. 10,000 is
} 
For the year 2000-01, total income taxes deducted amounted to Rs. $8,92,768$. In the table, total costs of compliance are estimated at 11.81 percent of taxes deducted at source

The aggregate estimate is based on this case study. It will be biased downward, if the average number of income tax paying employees per organisation is below 70 and if the dispersion of organisations by number of tax paying employees is large. Secondly, the cost of tax deduction at source for interest and dividend income is likely to lower per taxpayer than it is for salary income. Since 60 percent of taxes are collected through TDS, assuming that 80 percent of TDS is for employment income and that the cost of TDS for other income is 0.5 percent of taxes collected, the estimate of TDS compliance costs is $(0.6)(0.8)(11.81)+(0.6)(0.2)(0.05)$ or 5.68 percent of tax collections.

\section{Costs of Collecting Taxes through the Public Sector Banks}

Public sector banks are authorised to collect taxes and deposit them in the government treasury account at the Reserve Bank of India, Nagpur. Banks are compensated at the rate Rs. 11.80 per thousand rupees collected. This straightaway gives us the cost of collecting taxes by the Government at 1.18 percent of taxes collected. Therefore, banks were paid around Rs. 334 crore (1.18 percent of total income tax collection of Rs. 31,674 crore) for 2000-01. A major public sector bank in Mumbai estimated the cost actually incurred by banks to collect taxes and remit them to the government at around Rs. 22-23 per thousand, which is double the rate of reimbursement. If a rate of Rs. 22 is taken as the actual bank collection and remittance cost, then the additional third party cost of banks implied by this is Rs 10.20 per thousand or Rs. 363 crore for 2000-01.

\section{Cost of Appeals, Litigation and Prosecution}

In the absence of survey respondents with pending tax appeals or litigation or facing prosecution, a secondary data based estimate of representation costs of these proceedings is made from the report of the CAG (CAG, 2001 and earlier years) and from the fee estimates for such

assumed to be the share of TDS. The TDS share of costs of general supplies, stationery and consumables and maintenance was Rs. 62,308 per annum. 
cases made by the single CA firm responding to the survey. Table 25 presents fees reported for different proceedings by the firm of Chartered Accountants examined via a case study.

Information in reports of the CAG includes data on appeals pending before Commissioners (appeals) broken up by ranges of amounts in dispute. Data are also available for court cases and appeals before the ITAT (Income Tax Appellate Tribunal). After discussion with department officers, it is assumes, conservatively, that 40 percent of high demand appeals, 70 percent of low demand appeals, 40 percent of ITAT appeals and 0 percent of court references and writs are for non-company cases. Again conservatively, the incidence of appeals by salaried taxpayers is assumed at 5 percent of total appeals of each kind. With these assumptions and the fee rates in Table 25, estimates of litigation costs are in Table 26. It should be noted that additional time and money (and psychic) costs of taxpayers themselves are not included in these estimates.

\section{Administrative Costs of Collecting Taxes}

To complete the picture, administrative costs of collecting taxes should be added. Cost are directly or indirectly incurred by other departments and ministries besides the income tax administration itself, including by:

- The Department of Revenue including the Central Board of Direct Taxes.

- The Finance, Law (Income Tax Appellate Tribunal or ITAT) and Home ministries (Police).

- The Central Public Works Department.

- The Comptroller and Auditor General (for audit of the Income-tax department).

- The Public Accounts Committees of Parliament.

Of these costs, budgetary figures were obtained for the ITAT (Rs. 17.16 crore, revised estimate for 2000-01) and for the Settlement Commission for the year 1999-2000 (Rs. 4.12 crore). ${ }^{27}$ An additional amount of Rs. 5 crore is conservatively taken as the expenditure of other

${ }^{27}$ Government of India, Budget 2000-01, Notes on Demand for Grants. 
government departments on account of the individual income tax. The figure obtained from the Ministry of Finance for the revenue expenditure of the income-tax department is Rs. 870 crore for 2000-01. Following the apportionment of costs between taxes by the CAG for 1999-2000 (including prorating of the head "Direction and administration"), 87.3 percent is taken to be the share of cost attributable to the non-corporate income tax. This gives a cost of collection of the income tax of Rs. 759 crore for the year 2000-01. ${ }^{28}$

\section{Aggregate Estimates}

For sample based costs, the aggregation methodology is described in the Annex. Briefly, aggregate compliance costs as a percentage of total taxes paid and GDP, are inflated using total income taxes collection in 2000-01 from Government of India budget documents, and GDP at factor cost for the year 2000-01 (provisional estimate) from the Economic Survey. For taxpayer and gross income distributions, on which compliance cost distributions are based, CAG and Income-tax department estimates were used as explained further in the Annex and in Chattopadhyay and Das-Gupta (2002). However, where sample observations are missing for any cell (i.e. cost component for an income group), the minimum sample figure for the component over all groups is assumed, regardless of progressive or regressive trends. While this biases estimates downward, they are high enough as it is.

For the alternate, median based estimates (a) the proportion of salaried and non-salaried taxpayers (17.91 percent and 82.09 percent) is applied to deflated sample medians. ${ }^{29}$ (b) Given the high income bias in the sample, the ratio of the estimated median gross income of all taxpayers (Rs 99,465) to median sample income (Rs 155,699) is used to deflate sample medians. The high median money and bribe compliance costs of the non-salaried in the sample leads to these estimates being higher than the downward biased average based

${ }^{28}$ In keeping with our conservative approach, Ministry of Finance information on costs was used because these figures were recent and lower than the 1999-2000 cost of collection figure of $3.07 \%$ of personal income taxes in CAG (2001). Capital costs and the market value of government land and buildings is not accounted for anywhere, though it represents the true opportunity cost of premises occupied.

${ }^{29}$ As a further measure of conservatism, since median time + median monetary costs are below median legal compliance costs the former are reported. 
estimates. However, legal compliance costs are lower, due to low median time costs.

Estimates are in Table 27.

Adding case study based estimates of TDS, bank costs, appeals and non-filer costs to survey based estimates, gives total private compliance costs of around 59.5 percent (Table 28). Addition of administrative costs to this gives "the gross operating cost" of the personal income tax. Bribe payments, being transfers between individuals, need to be deducted from this to arrive at the social cost, which amounts to just under 60 percent of tax revenue. It is worth reiterating that these estimates, while alarming, rest on shaky foundations.

\section{Qualitative Information on Compliance Costs of Inefficiency and Corruption}

Qualitative information on the cost of bribes, harassment and poor administration, from open ended questions in the survey and focus group meetings, is now summarised.

\section{Bribes and Inefficiency in Relation to Refunds}

At least four respondents claimed that they had to pay bribes in order to obtain tax refunds, and that these bribes were paid on the advice of their tax advisor, The going rate of bribes, mentioned in 3 cases, was 10 percent of the refund due. In open ended questions several respondents highlighted procedural difficulties in getting refunds or non-receipt of refunds from past years.

\section{Other Comments on Bribes and Harassment}

Other comments made by respondents and during focus group meetings during the study on bribes and harassment included. 
"Personnel in the IT dept should be prompt and honest in discharging their duties and bring more revenue to the government rather than to themselves to make the department cost effective. They should stop harassing gullible and prompt taxpayers. Strict laws shouldn't be a tool to harass assessees."

"Bribes are 25 percent of tax paid for all booksellers under threat of revaluation of stock - even though actual stock is reported."

"Non-official expenses with income and sales tax is very high."

"Laws are complex and officials are corrupt"

"Tax laws are complicated, lots of hassles in submitting the form, and there is generally corruption and inefficiency in the system."

The following additional comments were made by members of the Bombay Chartered Accountants Society at a focus group meeting.

- To get clearances (e.g. under section 230A for transfer of immoveable properties) bribes had invariably to be paid to income tax officials.

- To avoid harassment, the opportunity cost of which was (e.g.) Rs. 20,000 a bribe of Rs. 5,000 was typically paid.

- Lengthy time delays in appeals were exacerbated by an inadequate number of benches though additional benches had recently been sanctioned.

- Lack of integrity of Income tax officials and assessing officer's fear of targets lead to significant compliance costs to taxpayers.

- A large proportion of advisors fees were to cover the cost of "idle time" waiting for appointments, meetings and hearings, often on benches outside the rooms of concerned ITD officials.

\section{Obtaining Permanent Account Numbers (PAN)}

With computerisation of the IT Department, new PAN numbers and photo identity cards were instituted by the Department in 1995. Delays in issuing PAN numbers are an almost pure representation of inefficiency as bribe opportunities are bound to be low. Eight respondents complained about difficulties in obtaining a PAN. Of this, six respondents reported the following time durations to get a PAN: (a) 3 months; (b) 6 months (c) 6-8 months (d) "Applied for on 26-6-99, but still waiting to get it"; (e) "PAN pending for 2 years"; (f) "PAN awaited for 3 years". 


\section{Conclusions}

The major conclusions of this study of compliance costs of the personal income tax in India are now summarised.

- The estimates of compliance costs of the personal income tax in India thrown up by this study are extraordinarily high, even though a strategy of deliberate underestimation was followed.

- Costs are high for salary earners, but at around 7-10 times the costs of salary earners, are excessive for non-salaried taxpayers.

- Costs are regressive and, for low income and middle income nonsalary earners, can be more than double the taxes paid even if bribe costs are neglected.

- Both the incidence of bribe payment and the bribe quantum are high, even among salary earners, but especially for non-salary earners.

- Harassment of assessees in various forms, whether related to bribes or not, is a serious problem adding to tax compliance costs.

- Costs borne by taxpayers amount to 6.8 percent of the gross income of taxpayers or 49 percent of personal income tax collections. If third party compliance costs are added, this rises to 56 percent of taxes collected. If estimated non-filer costs are added this rises to 59 percent of tax revenue.

- The estimates above do not include psychic costs. follows.

Our other conclusions, which have implications for policy are as

- Advisors are used more to deal with tax uncertainty and administrative procedures than to help in reducing tax burdens through tax planning - though the latter is not unimportant.

- Third party costs of deducting tax at source amounted, in a case study, to 11.8 percent of taxes withheld.

- Commercial bank costs of receiving and remitting taxes, over and above reimbursement received from the government, amounted to an estimated Rs. 363 crore or about 1 percent of tax collections.

- Delayed refunds are a cause of much harassment and, according to several salaried respondents, associated with forced bribe payments by salary earners. 
- Long delays in receipt of PAN cards and numbers are a source of harassment.

- Appeals, due to their long duration and the fact that the IT Department has been alleged to lose most appeals, lead to avoidable cost to both taxpayers and government. The falling trend during the past 3 years in filed and pending appeals is a welcome beginning.

\section{Reform Suggestions and Assessment of Recommendations of the Direct Tax Task Force}

Given the high compliance costs this survey has found, the personal income tax has emerged as indeed an exceptionally high cost source of funds, certainly by international standards but also possibly in relation to other competing sources of funds in the Indian context. This is partly, but only partly, due to the widespread corruption in the Department that the study finds. The high compliance costs have much more to do with cumbersome procedures and, to a lesser extent, substantive tax provisions. A six-pronged approach to reducing the operating cost of the personal income tax is therefore suggested: Tax structure simplification, institutional reform, procedural reform, automation, monitoring and client feedback and tax policy process reform. If this proves to have an inadequate impact on compliance costs in, say, around 3 years, then drastic tax reform is possibly worth considering seriously to reduce the cost to society of raising government revenue is required.

Of these, tax structure simplification has been extensively discussed by the Direct Tax Task Force (Government of India, Ministry of Finance, 2002). Though some suggestions have been found debatable in public discussion, simplification is not examined here as their recommendations will, broadly, reduce the complexity of the income tax. 


\section{Reforming Administration Institutions and Incentives}

If the personal income tax is persisted with in India, then a key reform strategy is to ensure that the income tax administration genuinely wants to reduce taxpayer costs because it is in their interest to do so. This is the most important reform component for a successfully functioning income tax. ${ }^{30}$

Current institutional problems are reflected in (a) continued reliance on excessive discretion to low level officers who have limited accountability resulting in procedures and a mind set that is antitaxpayer; (b) a widespread culture of bribes and unhelpful treatment of taxpayers; and (c) an archaic organisation structure, which is taxpayer based under a single officer system, rather than organised along modern, functional lines.

Important reforms suggested are:

- Organisational reform of top management including stability and security of tenure. ${ }^{31}$

- Functional reorganisation of the Income-tax Department to break the single officer - single taxpayer nexus and simultaneously reap gains from specialisation.

- This should include, importantly, a separate taxpayer services division.

- Introduction, as a necessary precondition, of transparent and nondiscretionary performance measurement for all units, each staff

${ }^{30}$ It should be noted that income tax administration involves government organs besides the income tax department which also require examination and reform in order to lower operating costs of the income tax. Secondly, the viewpoint expressed here, if acceptable, implies a criticism of the Direct Tax Task Force (Government of India, Ministry of Finance, 2002 abbreviated in this chapter as "the Kelkar Task Force") since reforms they suggest fail to adequately address incentives of officials and related institutional reforms.

${ }^{31}$ As suggested by the Kelkar Task Force which draws on earlier reform suggestions.

32 A partial organizational restrucuturing along functional lines, which was under consideration by the Income Tax Department in the wake of its recent cadre resrtructuring has, it is reported, recently been shelved. 
member, each taxpayer related activity and also the tax department as a whole. ${ }^{33}$

- Performance measures should not only be linked to revenue collections but also to efficiency and to improvements in taxpayer feedback on tax department services.

- Public performance reporting via annual. ${ }^{34}$

- Organisational and individual incentives - both positive and negative $^{35}$ - linked to performance. ${ }^{36,37}$

- Strengthened external monitoring by existing organs such as the CAG, Central Vigilance Commission, and also the Tax Ombudsman proposed by the Kelkar Task Force.

- These reforms, coupled with taxpayer friendly automation, which also increases the deterrent capacity of the department, will help in ending this current pernicious cultural orientation of the department.

\section{Reforming Procedures}

Substantial improvement in the efficiency of taxpayer related procedures coupled with much better taxpayer services provided by the Income tax department is needed.

The Kelkar Task Force has suggested several welcome reforms, particularly for refunds, clearances, tax payment and, to a lesser extent,

${ }^{33}$ This is recommended by a variety of scholars (see, Das-Gupta, 2002) and has also been adopted by the Commercial Tax Department in Andhra Pradesh. See, also Febres et. al. (1998).

${ }^{34}$ The report structure recommended by the Kelkar Task Force is, however, inadequate.

35 Negative incentives should include effective penalties for corrupt officials with an appropriately nuanced, partial shifting of the burden of proof on them.

${ }^{36}$ The Kelkar Task Force draws a negative lesson from the negative effects of current rewards for the Investigation wing of the income-tax department. However, the correct lesson from rewards for searches appears incentives work - but piecemeal incentives distort effort. Incentivising the entire administration is, it appears, the correct lesson to draw: Don't abolish rewards - redesign them. For example, a fairly common incentive for the entire tax administration is a rule linking the budget to performance achievement (in terms of revenues and independent taxpayer feedback) relative to targets. For recent evidence on the general efficacy of well designed rewards in in tax administration seethe World Bank (1999). See, also Milgrom and Roberts (1992) for private sector evidence.

37 A serious omission by the Kelkar Task Force is that of budget allocation for tax departments being used as an incentive. They do, however, suggest - but without spelling out details - increased flexibility and discretion for them over resource and manpower deployment. 
for scrutiny. They have also suggested improvements in assistance to taxpayers. ${ }^{38}$ However, the recommendations fall short of what is needed as no clear performance benchmarks are suggested, nor do they outline an appropriate scheme for performance monitoring of the proposed reforms. These need to be chalked out.

Some additional suggestions can also be made.

- The burden on small taxpayers, particularly those from the nonsalaried class, is unacceptably high, notwithstanding the presumption of greater evasion among these taxpayers. Two wrongs, both of which harm society, cannot cancel out. Besides improved services, reintroduction of (redesigned) simplified, presumptive, tax assessments for small taxpayers is suggested.

- This is also true for other non-salaried taxpayers. This suggests that simpler tax rules for unincorporated taxpayers with business or professional income and greater recourse to TDS in the case of selected professionals may reduce their costs as also their scope for tax evasion.

- For salary earners, a possibly radical suggestion is to do away with taxation of central government salaries along with a neutral pay cut. This will result in administration and compliance cost saving, reduced government revenue expenditure offsetting reduced revenue. However, the reduced administration cost implies a lower fiscal deficit. $^{39}$

- For such procedures as scrutinies and appeals, automation will enable the success rates of the tax department to be tracked. Once this is done, benchmark success ratios can be laid down as part of their performance indicators.

\section{Automation}

The finding of high compliance costs lends greater force to criticisms being levelled against the Income-tax Department for its slow and dysfunctional progress in automation. While this is recognised by the Kelkar Task Force, their recommendations do not have linked

${ }^{38}$ The scrutiny suggestions of the committee unfortunately lay almost exclusive emphasis on case selection giving little attention on the actual scrutiny procedure.

${ }^{39}$ However, the devolution share of states will need to be increased to compensate their revenue loss from falling income tax collections. 
organisational and human reform components. Without these there is an appreciable risk of failure. ${ }^{40}$

Automation should first focus on the woefully adequate PAN data base and tax collections as recognised by the Kelkar Task Force. Networking for improved enforcement, automation of taxpayer services, and development of a performance indicator based MIS can then be scheduled, with remaining applications being scheduled last. ${ }^{41}$

\section{Improving Monitoring, Reporting and Client Feedback}

These have already been outlined in a previous subsection. A point requiring clarification is client or taxpayer feedback: This should be required for every case of a taxpayer dealing directly or through a representative with a tax official. Furthermore, the form should (a) be anonymous but identify the tax official; (b) be sent directly to an independent body (such as the proposed Tax Ombudsman or even to a private agency retained for the purpose) and (c) be reported in the tax departments annual report as is done, for example, by the United Kingdom's Inland Revenue Service. The second point concerns proper annual reporting. A suggested structure is in the accompanying Box.

\section{BOX: Annual Reporting of Performance}

The general goal of a tax administering department should be "to collect taxes legally due by providing taxpayer education, assistance and compliance enforcement at minimum social cost". This implies a focus on effectiveness and efficiency of tax collection. Effectiveness reflects tax collection relative to potential as per law. Efficiency reflects the cost to society per rupee of revenue raised. It has 3 measurable components: (i) The resource cost of tax administration -

${ }^{40}$ IT projects have a had a high rate of failure even in developed countries due to neglect of human resources and institutional reform. See, for example, Clegg et. al. (1997) and Ross and Weill (2002). In tax administrations, a glaring example is the USA's Internal Revenue Service whose efforts over the past 50 years have been unsatisfactory. See, Barbone et. al. (1999).

41 See, Das-Gupta and Mookherjee (1998) and Barbone et. al. (1999) for international experience of tax administration automation. 
as reflected in budgetary expenditure; (ii) resources expended on tax administration by the rest of government (including of the Finance Department, PWD, Police, Law Department and Tribunals, AG's office, etc), and (iii) the compliance cost of taxpayers and third parties.

Annual reports of tax administrations should focus on achievement relative to the estimated magnitude of the problem (e.g. new registrations relative to estimates of current non-filers), NOT on relatively uninformative achievements or growth rates per se.

Reports should provide information on:

- Mission and vision statements

- Staff strength, physical resources and infrastructure, organisation and functions of divisions.

- Recruitment, promotions and transfers.

- Achievements against action plan for the year overall and by major activities.

- Manpower improvement activities (training) and infrastructure upgrading with cost details.

- Targets for the year against revenue collected and administrative expenditure.

- Effectiveness indicators relative to targets in terms of revenue effects for each activity and program.

- Workload and efficiency (cost-to-revenue) indicators.

- Results of taxpayer feedback on quality and timeliness of services and corruption encountered, external (CAG) audit, ombudsmen's evaluation, vigilance and parliamentary review.

- Targets for the next year.

- Administrative reforms planned next year and in future with cost estimates and performance benchmarks.

- Multi-year information where possible - for MIS and research purposes.

\section{Reforming the Policy Process}

The Kelkar Task Force has suggested cost-benefit analysis of new proposals for revenue expenditures. The government may wish to add to this limited compliance cost and administrative cost assessments 
to rationally decide if the extra revenue benefits are worth the attendant compliance costs.

A negative aspect of the tax policy process is the role played by high powered committees which deal with administrative reform. Ideally, reforms should be presented as a package which includes implementation plans, costs, and targeted performance levels. Furthermore, implementation of the (accepted) reforms should ideally be overseen by a member of the committee. This forces a measure of realism and accountability on the committee and raises the chance of success. Furthermore, proper "change management" has been recognised as important for successful institutional reform.

\section{Overhauling the Tax System: A Medium Run Option}

The high cost of collecting the income tax suggests that the government should greatly reduce its reliance on the income tax in its current form, if administrative efficiency cannot be greatly improved, and explore alternative revenue sources such as presumptive levies, increased TDS, and also indirect taxation if the move to a full VAT is eventually successful. In fact, that a greater reliance on deficit finance, widely seen as the worst possible revenue raising alternative, will be socially superior to the personal income tax cannot be ruled out without further careful examination. A much simplified tax code relying on automatic, presumptive levies which minimize taxpayer compliance requirements is needed and a preliminary attempt is now made to outline such a system.

In particular reforms worth considering are:

- A "retrograde" return to schedular income taxation consisting of:

- TDS as a final withholding tax for salary and interest income.

- House rent income taxed by "piggy-backing" on the local property tax.

- Similar piggy-backing for capital gains via an additional stamp duty (at a suitably low rate) on asset sales. 
- Unincorporated business and professional income taxed presumptively on the basis of a few, observable, indicators as in Israel. ${ }^{42}$

- Periodic increasing of the exemption limit in line with inflation.

${ }^{42}$ See, Das-Gupta and Mookherjee (1998) and references cited there. Also see, Rajaraman (1997). 
Table 1: Recent Individual Income Tax Compliance Cost Estimates for Other Countries (percentages of tax revenue)

\begin{tabular}{|c|c|c|c|c|c|c|}
\hline Country & Year & Individuals & $\begin{array}{l}\text { Employers } \\
\text { (PAYE) }\end{array}$ & $\begin{array}{l}\text { Other } \\
\text { private } \\
\text { costs }\end{array}$ & $\begin{array}{l}\text { Admini } \\
\text { strative } \\
\text { costs }\end{array}$ & $\begin{array}{l}\text { Total } \\
\text { operating } \\
\text { costs }\end{array}$ \\
\hline Australia $^{a}$ & $1986-87$ & $7.9-10.8$ & 1.26 & & 1.13 & 10.29 \\
\hline $\mathrm{Do}^{\mathrm{b}}$ & $1990-91$ & 9.2 & 1.6 & & 1.1 & 11.9 \\
\hline $\mathrm{Do}^{\mathrm{c}}$ & $1994-95$ & $7.9(4.00)$ & & & & \\
\hline Canada $^{a}$ & 1986 & 2.53 & 3.57 & 0.03 & 1.00 & 7.13 \\
\hline $\begin{array}{l}\text { Federal Republic } \\
\text { of Germany }\end{array}$ & 1984 & $0.75^{6}$ & & & 2.35 & \\
\hline Israel $^{\circ}$ & 1987 & 1.32 & & & & \\
\hline Netherlands $^{k}$ & 1989 & $1.4^{5}$ & & & & \\
\hline New Zealand ${ }^{\mathrm{i}, \mathrm{k}, \mathrm{l}}$ & 1992 & 8.1 & & & 1.0 & 9.1 \\
\hline Norway ${ }^{1, m}$ & c. 1988 & 2.7 & & & 1.7 & 4.4 \\
\hline Sweden $^{p}$ & $1990-91$ & 0.88 & 0.11 & 0.17 & 0.65 & 1.81 \\
\hline United Kingdom $^{a}$ & $1986-87$ & 2.21 & 1.02 & 0.17 & 1.53 & 4.93 \\
\hline $\mathrm{Do}^{\mathrm{d}}$ & $1986-87$ & 2.8 & & & 1.1 & 3.9 \\
\hline $\mathrm{Do}^{\mathrm{e}}$ & $1983-84$ & 3.6 & & & & \\
\hline U.S.A. ${ }^{f}$ & 1982 & $5-7$ & & & & \\
\hline $\mathrm{Do}^{\mathrm{g}, \mathrm{h}}$ & 1994 & 5.8 & & & & \\
\hline $\mathrm{Do}^{\mathrm{g}}$ & 1995 & 9.0 & & & & \\
\hline
\end{tabular}

Notes and Sources:

a: Sandford (1994a).

b. Pope (1994).

c. Binh et. al. (2000). The $4 \%$ Social compliance costs (SCC) equals imputed costs of time and resources spent by taxpayers plus their expenditure less managerial benefits. The $7.9 \%$ taxpayer compliance costs equal SCC less cash flow and tax deduction benefits.

d. Sandford, Godwin and Hardwick (1989). Estimates are for central government taxes.

e. Binh et. al. (2000) using information in Hite and Sawyer (1997).

f. Slemrod and Sorum (1984). Includes both federal and state income tax revenue.

g. Binh et al (2000) using data from Slemrod (1995). 
Table 1: Recent Individual Income Tax Compliance Cost Estimates for Other Countries (percentages of tax revenue)

\begin{tabular}{|c|c|c|c|c|c|c|}
\hline Country & Year & Individuals & $\begin{array}{l}\text { Employers } \\
\text { (PAYE) }\end{array}$ & $\begin{array}{l}\text { Other } \\
\text { private } \\
\text { costs }\end{array}$ & $\begin{array}{l}\text { Admini } \\
\text { strative } \\
\text { costs }\end{array}$ & $\begin{array}{l}\text { Total } \\
\text { operating } \\
\text { costs }\end{array}$ \\
\hline
\end{tabular}

h. Hite and Sawyer (1997) using data from Slemrod (1995).

i. Using estimates from Slemrod (1995) for the USA and McCulloch (1992) for New Zealand, Hite and Sawyer (1997) derive comparable estimates of compliance costs for New Zealand and the USA.

j. Allers (1994).

k. Hite and Sawyer (1997) using data from McCulloch (1992).

I. Only for the self-employed individuals.

m. Nicolaissen (1989).

$\mathrm{n}$ Fischer (1989). The ratios could be underestimated since the base could be total tax revenue. o. Friedkes and Gavish (1989).

p. Malmer (1995). Figures here are computed from his Tables 32 and 33 for income and payroll taxes. VAT and excise duty estimates are excluded. Including all 4 taxes, compliance costs are $1.97 \%$ of tax revenue or around $1 \%$ of Swedish GDP.

5 See, Kaplow (1995).

$6 \quad$ See also McClure (1989), Boucher (1991), Pope (1994), Talib (1996), Bardsley (1996) and James, Sawyer and Wallschutzky (1997). 
Table 2: Gross Income, Taxes, Effective and Marginal Tax Rates: Sample Averages

\begin{tabular}{|c|c|c|c|}
\hline & Non salary & Salary & All \\
\hline Average gross income: AllTS-CAG & N.A. & N.A. & $1,19,252$ \\
\hline Average tax paid: AlITS-CAG & N.A. & N.A. & 16,187 \\
\hline $\begin{array}{l}\text { Average tax paid as a \% of Average Gross Income: } \\
\text { AllTS-CAG } \\
\text { Income and Tax Saving }\end{array}$ & N.A. & N.A. & 13.58 \\
\hline Estimated gross income (Rs.) & $2,86,138$ & $1,91,044$ & $2,13,744$ \\
\hline Income tax saving (rebates and deductions in Rs.) & 6,835 & 9,262 & 8669 \\
\hline \multicolumn{4}{|l|}{ Tax payments } \\
\hline Estimated income tax paid (Rs) & 66,001 & 21,334 & 32,642 \\
\hline Tax deducted at source (Rs) & 23,503 & 17,955 & 19,399 \\
\hline Refund due or received (Rs) & 0.00 & 2336 & 1475 \\
\hline Average marginal tax rate $(\%)$ & 18.72 & 20.96 & 20.45 \\
\hline Average effective tax rate (\%) (i.e. $\left.\frac{1}{n} \sum \frac{T_{i}}{Y_{i}}\right)^{*}$ & 11.00 & 7.41 & 8.21 \\
\hline $\begin{array}{l}\text { Average tax paid as a \% of average gross income (i.e. } \\
\left.\frac{\left[\sum \mathrm{T}_{\mathrm{i}}\right] / \mathrm{N}}{\left[\sum \mathrm{Y}_{\mathrm{j}}\right] / \mathrm{M}}\right)^{\star}\end{array}$ & 23.07 & 11.17 & 15.27 \\
\hline Total responses* & 20 to 40 & 20 to 118 & $\begin{array}{r}40 \text { to } \\
158 \\
\end{array}$ \\
\hline
\end{tabular}

Notes: AlITS-CAG: Estimates by Chattopadhyay and Das-Gupta (2002) based on data from various issues of the All India Income Tax Statistics and Reports of the Comptroller and Auditor General.

*: The number of responses used for different rows varies due to missing observations. So an average tax rates for all observations together is presented in addition to the average effective tax rate over available observations. 
Table 3: Respondents Under Scrutiny

\begin{tabular}{|c|c|c|c|c|c|c|}
\hline \multirow{4}{*}{$\begin{array}{l}\text { Mean } \\
\text { Observat }\end{array}$} & \multicolumn{3}{|c|}{$\begin{array}{c}\text { Respondents who spent time or } \\
\text { money due to scrutiny proceedings } \\
(\%)\end{array}$} & \multicolumn{3}{|c|}{$\begin{array}{c}\text { Respondents scrutinised in the current } \\
\text { year }(\%)\end{array}$} \\
\hline & Non-salary & Salary & All & Non-salary & Salary & All \\
\hline & 21.74 & 9.57 & 13.04 & 6.52 & 3.48 & 4.35 \\
\hline & 46 & 115 & 161 & & & \\
\hline
\end{tabular}

Table 4: How Tax Returns Are Completed

\begin{tabular}{lcccc}
\hline & \multicolumn{2}{c}{ Number of responses } & \multicolumn{2}{c}{ Percentage of total responses } \\
& Non-salary & Salary & Non-salary & Salary \\
\hline By taxpayer & 9 & 37 & 18.0 & 32.5 \\
By friend(s) & 2 & 39 & 4.0 & 34.2 \\
By advisor & 39 & 38 & 78.0 & 33.3 \\
Total responses & 50 & 114 & 100.0 & 100.0 \\
\hline
\end{tabular}

Table 5: Time Spent Helping Others Comply

\begin{tabular}{lcccc}
\hline & \multicolumn{2}{c}{ Number of responses } & Percentage of total responses \\
\hline & Non salary & Salary & Non salary & Salary \\
Did not help & 16 & 32 & 51.6 & 32.3 \\
2 hours or less & 1 & 6 & 3.2 & 6.1 \\
3 to 5 hours & 8 & 20 & 25.8 & 20.2 \\
6 to 10 hours & 3 & 9 & 9.7 & 9.1 \\
10 hours or more & 3 & 32 & 9.7 & 32.3 \\
Total responses & 31 & 99 & & \\
Average hours & 3 hrs 0 mins & $\begin{array}{c}5 \text { hrs } 28 \\
\text { mins }\end{array}$ \\
\hline
\end{tabular}


Table 6: Fees paid to (Professional) Tax Advisors

\begin{tabular}{lcccc}
\hline & \multicolumn{2}{c}{ Number of responses } & \multicolumn{2}{c}{ Percentage of total responses } \\
\hline Rs. 500 or less & Non salary & Salary & Non salary & Salary \\
Rs. 501 to 2000 & 2 & 22 & 6.3 & 56.4 \\
Rs. 2001 to 5000 & 14 & 14 & 43.8 & 35.9 \\
Rs. 5001 to 20000 & 8 & 3 & 25.0 & 7.7 \\
Rs. 20000 or more & 5 & 0 & 15.6 & 0.0 \\
Average (Rs) & 3575 & 459 & 9.4 & 0.0 \\
Coefficient of variation & 1.93 & 1.67 & N.A. & N.A. \\
Number of observations & 32 & 39 & & N.A. \\
\hline
\end{tabular}

Note: N.A.: not applicable.

Table 7: Why Tax Advisors Are Engaged (average scores)

\begin{tabular}{lcc}
\hline & Non Salary & Salary \\
\hline Frequent change in tax laws & 2.5 & 4.7 \\
Complex tax affairs & 1.7 & 3.3 \\
Not sure of tax administration procedures & 2.4 & 3.7 \\
Not sure of prompt and courteous guidance from tax & 1.9 & 3.6 \\
administration & & 4.1 \\
To reduce tax burden & 3.4 & 4.6 \\
To ensure perfection in tax documents & 3.0 & 3.0 \\
It is cheaper to hire a tax advisor & 3.0 & N.A. \\
Other reasons & 2.0 & 8 \\
Total questionnaires & 23 & \\
\hline
\end{tabular}

Note: 'Very important=5, Quite important=4, Neutral=3, quite unimportant=2, unimportant $=1$.

Table 8: Monetary Compliance Costs

\begin{tabular}{|c|c|c|c|c|c|c|c|c|c|}
\hline & \multicolumn{3}{|c|}{ In Rupees } & \multicolumn{3}{|c|}{ As a percentage of tax } & \multicolumn{3}{|c|}{$\begin{array}{l}\text { As a percentage of } \\
\text { income }\end{array}$} \\
\hline & $\begin{array}{l}\text { Non- } \\
\text { salary }\end{array}$ & Salary & All & $\begin{array}{l}\text { Non- } \\
\text { salary }\end{array}$ & Salary & All & $\begin{array}{l}\text { Non- } \\
\text { salary }\end{array}$ & Salary & All \\
\hline Average & 15163 & 921 & 4683 & 171.9 & 30.4 & 58.7 & 6.01 & 0.61 & 1.67 \\
\hline Median & 1485 & 858 & 948 & 52.0 & 1.6 & 14.1 & 3.00 & 0.13 & 0.26 \\
\hline $\begin{array}{l}\text { Coefficient of } \\
\text { variation }\end{array}$ & 2.0 & 2.1 & 3.6 & 2.1 & 4.3 & 3.5 & 1.7 & 2.4 & 3.0 \\
\hline Observations & 33 & 115 & 148 & 23 & 92 & 115 & 31 & 113 & 144 \\
\hline
\end{tabular}


Table 9: Average Value of Components of Monetary Compliance Costs (in Rs.)

\begin{tabular}{lccc}
\hline Activities & Non-salary & Salary & All \\
\hline Record keeping & 6605 & 95 & 1620 \\
Tax planning and research & 429 & 189 & 245 \\
Filing of tax return & 960 & 176 & 359 \\
Obtaining PAN & 60 & 62 & 62 \\
Fees paid to the advisor & 5575 & 459 & 2275 \\
Other monetary costs & 1534 & 60 & 122 \\
Total monetary cost (excl & $\mathbf{9 5 8 8}$ & $\mathbf{5 8 1}$ & $\mathbf{2 4 0 8}$ \\
advisor fees) & $\mathbf{1 5 1 6 3}$ & $\mathbf{9 2 1}$ & $\mathbf{4 6 8 3}$ \\
Total monetary cost & 2.83 & 18.14 & 5.24 \\
\% on Tax planning and research & &
\end{tabular}

Note: 1 Scrutiny, tax refund, in appeal and litigation, and others.

Table 10: Hours Spent in Complying with Income Tax Laws (Sample Averages)

\begin{tabular}{lccc}
\hline Activity & Non-salary & Salary & All \\
\hline Record keeping & 67.8 & 7.3 & 20.9 \\
Completing and submitting tax return & 5.2 & 5.2 & 5.2 \\
Tax planning and research & 7.2 & 8.2 & 8.0 \\
Obtaining a Permanent Account Number (PAN) & 1.3 & 2.6 & 2.3 \\
Any other tax related activities* & 6.6 & 4.5 & 4.8 \\
Total Hours Spent & $\mathbf{8 8 . 1}$ & $\mathbf{2 7 . 9}$ & $\mathbf{4 1 . 3}$ \\
\% on Tax Planning and research & 8.20 & 29.41 & 19.33 \\
\hline
\end{tabular}

Note: *: Time spent on scrutiny, tax refund, in appeal matters and unspecified activities.

Table 11: Hourly Value of Time and Average Hourly Earnings (in Rs)

\begin{tabular}{lrrr}
\hline Time Value & Non-salary & Salary & All \\
\hline Self assessed value per hour (pre-tax) & 761 & 211 & 402 \\
Self assessed value per hour (after tax adjustment) & 750 & 199 & 391 \\
Average pre-tax hourly earnings & 149 & 99 & 111 \\
Average post-tax hourly earnings & 132 & 83 & 95 \\
Average conservative value of time per hour & 135 & 77 & 93
\end{tabular}

Note: The number of observations in reported averages is not uniform, given missing data, explaining the higher conservative value compared to post-tax hourly earnings for the nonsalaried. 
Table 12: Time Compliance Costs (at conservative values of time per hour)

\begin{tabular}{|c|c|c|c|c|c|c|c|c|c|}
\hline & \multicolumn{3}{|c|}{ In rupees } & \multicolumn{3}{|c|}{ As a percentage of tax } & \multicolumn{3}{|c|}{$\begin{array}{c}\text { As a percentage of } \\
\text { income }\end{array}$} \\
\hline & $\begin{array}{l}\text { Non- } \\
\text { salary }\end{array}$ & Salary & All & $\begin{array}{l}\text { Non- } \\
\text { salary }\end{array}$ & Salary & All & $\begin{array}{l}\text { Non- } \\
\text { salary }\end{array}$ & Salary & All \\
\hline Average & 26880 & 2086 & 7614 & 75.70 & 31.60 & 39.96 & 3.72 & 1.17 & 1.71 \\
\hline Median & 1485 & 858 & 948 & 17.38 & 7.14 & 8.79 & 0.78 & 0.49 & 0.55 \\
\hline $\begin{array}{l}\text { Coefficient of } \\
\text { variation }\end{array}$ & 4.1 & 1.7 & 6.9 & 1.5 & 3.2 & 2.6 & 2.2 & 1.9 & 2.6 \\
\hline Observations & 33 & 115 & 148 & 22 & 94 & 116 & 31 & 115 & 146 \\
\hline
\end{tabular}

Table 13: Average Value of Components of Time Compliance Costs (in Rs)

\begin{tabular}{lccc}
\hline Activities & Non-salary & Salary & All \\
\hline Average value of record keeping & 25047 & 590 & 6118 \\
Completing and submitting tax return & 602 & 409 & 453 \\
Tax planning and research & 505 & 627 & 599 \\
Obtaining a Permanent Account Number (PAN) & 121 & 169 & 143 \\
Other tax related activities* & 604 & 291 & 301 \\
Total Hours Spent & $\mathbf{2 6 8 8 0}$ & $\mathbf{2 0 8 6}$ & $\mathbf{7 6 1 4}$ \\
\% on tax planning and research & 1.88 & 30.08 & 7.87 \\
\hline
\end{tabular}

Note: *: Time spent on scrutiny, tax refund, in appeal matters and unspecified activities.

Table 14: Legal (Time and Money) Compliance Costs

\begin{tabular}{|c|c|c|c|c|c|c|c|c|c|}
\hline & \multicolumn{3}{|c|}{ In Rupees } & \multicolumn{3}{|c|}{$\begin{array}{c}\text { As a percentage of } \\
\text { tax }\end{array}$} & \multicolumn{3}{|c|}{$\begin{array}{l}\text { As a percentage of } \\
\text { income }\end{array}$} \\
\hline & $\begin{array}{l}\text { Non- } \\
\text { salary }\end{array}$ & Salary & All & $\begin{array}{l}\text { Non- } \\
\text { salary }\end{array}$ & Salary & All & $\begin{array}{l}\text { Non- } \\
\text { salary }\end{array}$ & Salary & All \\
\hline Average & 37168 & 3049 & 12074 & 255.36 & 61.35 & 98.15 & 10.05 & 1.79 & 3.52 \\
\hline Median & 5251 & 1296 & 1784 & 103.13 & 12.11 & 17.33 & 7.61 & 0.84 & 1.05 \\
\hline $\begin{array}{l}\text { Coefficient of } \\
\text { variation }\end{array}$ & 2.9 & 1.5 & 4.7 & 1.5 & 3.6 & 2.8 & 1.3 & 1.7 & 2.1 \\
\hline Observations & 41 & 114 & 155 & 22 & 94 & 116 & 30 & 113 & 143 \\
\hline
\end{tabular}


Table 15: Average Value of Legal Tax Planning Costs (as a Percentage of Total Legal Costs)

\begin{tabular}{ccc}
\hline Non-salary & Salary & All \\
\hline 2.22 & 26.10 & 6.87 \\
\hline
\end{tabular}

Table 16: Compliance Cost and Tax Saved as a Percentage of Gross Tax (Before Rebate and Tax Saved Through Deductions)

\begin{tabular}{lcccccc}
\hline & \multicolumn{2}{c}{ Legal compliance cost } & \multicolumn{3}{c}{ Tax saved } \\
& Non-salary & Salary & All & Non-salary & Salary & All \\
\hline Average & 120.91 & 23.03 & 39.22 & 45.33 & 43.16 & 43.60 \\
Median & 70.88 & 7.26 & 8.88 & 0.00 & 36.20 & 24.82 \\
Coefficient of & 1.20 & 2.05 & 2.06 & 0.61 & 0.74 & 0.71 \\
variation & & & & & & \\
Observations & 22 & 111 & 133 & 22 & 86 & 108 \\
\hline
\end{tabular}

Table 17: Effective Tax Rate Plus Legal Compliance Cost as a Percentage of Income

\begin{tabular}{|c|c|c|c|}
\hline & Non-salary & Salary & All \\
\hline Average & 18.39 & 9.36 & 11.18 \\
\hline Coefficient of variation & 1.01 & 0.76 & 0.98 \\
\hline Observations & 27 & 107 & 134 \\
\hline Average effective tax rate & 11.00 & 7.41 & 8.21 \\
\hline
\end{tabular}

Table 18: Bribes

\begin{tabular}{lccccccccc}
\hline & \multicolumn{3}{c}{ In Rupees } & \multicolumn{4}{c}{ As a percentage of tax } & \multicolumn{3}{c}{$\begin{array}{c}\text { As a percentage of } \\
\text { income }\end{array}$} \\
\cline { 2 - 11 } & $\begin{array}{c}\text { Non- } \\
\text { salary }\end{array}$ & Salary & All & $\begin{array}{c}\text { Non- } \\
\text { salary }\end{array}$ & Salary & All & $\begin{array}{c}\text { Non- } \\
\text { salary }\end{array}$ & Salary & All \\
\hline $\begin{array}{l}\text { Average } \\
\text { Coefficient of }\end{array}$ & 47629 & 1447 & 12993 & 48.22 & 10.93 & 18.92 & 6.51 & 0.78 & 2.21 \\
variation & 1.5 & 2.9 & 0.9 & 1.2 & 1.4 & 1.3 & 1.4 & 2.1 \\
Observations & 4 & 12 & 16 & 3 & 11 & 14 & 4 & 12 & 16 \\
\hline
\end{tabular}


Table 19: Respondents Claiming Harassment by Income Tax Officials

\begin{tabular}{lcccccc}
\hline & \multicolumn{3}{c}{ Percentage harassed by IT officer } & \multicolumn{3}{c}{ Harassment cost as a percentage } \\
& \multicolumn{3}{c}{ of tax paid } \\
\cline { 2 - 7 } & Non-salary & Salary & All & Non-salary & Salary & All \\
\hline Average & 14.29 & 23.08 & 20.00 & 2.78 & 6.43 & 5.00 \\
Coefficient of & N.A. & N.A. & N.A. & 3.00 & 3.74 & 3.85 \\
variation & & & & & & \\
Observations & 21 & 39 & 60 & 9 & 14 & 23 \\
\hline
\end{tabular}

Table 20: Legal and Bribe Compliance Costs

\begin{tabular}{|c|c|c|c|c|c|c|c|c|c|}
\hline & \multicolumn{3}{|c|}{ In Rupees } & \multicolumn{3}{|c|}{$\begin{array}{c}\text { As a percentage of } \\
\text { tax }\end{array}$} & \multicolumn{3}{|c|}{$\begin{array}{c}\text { As a percentage of } \\
\text { income }\end{array}$} \\
\hline & $\begin{array}{l}\text { Non- } \\
\text { salary }\end{array}$ & Salary & All & $\begin{array}{l}\text { Non- } \\
\text { salary }\end{array}$ & Salary & All & $\begin{array}{l}\text { Non- } \\
\text { salary }\end{array}$ & Salary & All \\
\hline Average & 41815 & 3201 & 13415 & 261.9 & 62.6 & 100.4 & 10.9 & 1.9 & 3.8 \\
\hline Median & 5751 & 1298 & 1840 & 130.7 & 12.6 & 18.4 & 8.3 & 0.9 & 1.1 \\
\hline $\begin{array}{l}\text { Coefficient of } \\
\text { variation }\end{array}$ & 2.8 & 1.5 & 4.6 & 1.5 & 3.5 & 2.7 & 1.3 & 1.6 & 2.0 \\
\hline Observations & 41 & 114 & 155 & 22 & 94 & 116 & 30 & 113 & 143 \\
\hline
\end{tabular}


Table 21: Estimates of Compliance Costs Costs as a Percentage of Gross Income by Range of Income: Salaried Respondents

\begin{tabular}{|c|c|c|c|c|c|c|}
\hline $\begin{array}{l}\text { Range-wise number } \\
\text { of respondents }\end{array}$ & 3 & 31 & 60 & 15 & 4 & 5 \\
\hline $\begin{array}{l}\text { Total number of } \\
\text { respondents }=118\end{array}$ & $\begin{array}{l}\text { Rs } 50000 \\
\text { or less }\end{array}$ & $\begin{array}{l}\text { Rs } 50-100 \\
\text { thousand }\end{array}$ & $\begin{array}{l}\text { Rs 100- } \\
200 \\
\text { thousand }\end{array}$ & $\begin{array}{l}\text { Rs 200- } \\
300 \\
\text { thousand }\end{array}$ & $\begin{array}{l}\text { Rs } 300- \\
400 \\
\text { thousand }\end{array}$ & $\begin{array}{l}\text { Rs } 4,00,000 \\
\text { and above }\end{array}$ \\
\hline Time spent & 0.48 & 1.56 & 1.08 & 1.45 & 0.54 & 0.55 \\
\hline Money spent & 0.31 & 0.86 & 0.59 & 0.16 & 0.31 & 0.36 \\
\hline Bribes paid & N.A. & 0.02 & 0.27 & 0.14 & 0.00 & 0.00 \\
\hline $\begin{array}{l}\text { Legal (time plus } \\
\text { money) compliance } \\
\text { costs }\end{array}$ & 0.79 & 2.42 & 1.67 & 1.61 & 0.85 & 0.91 \\
\hline $\begin{array}{l}\text { Legal + bribe } \\
\text { compliance costs }\end{array}$ & N.A. & 2.44 & 1.94 & 1.75 & 0.85 & 0.91 \\
\hline \multicolumn{7}{|c|}{ Memo Items } \\
\hline $\begin{array}{l}\text { Legal + bribe } \\
\text { compliance costs (as } \\
\text { a percentage of tax } \\
\text { paid) }\end{array}$ & N.A. & 103.54 & 25.01 & 13.66 & 3.66 & 4.02 \\
\hline $\begin{array}{l}\text { Legal + bribe } \\
\text { compliance costs (In } \\
\text { Rs) }\end{array}$ & N.A. & 2506 & 3331 & 4452 & 3113 & 6544 \\
\hline $\begin{array}{l}\text { Value of time spent } \\
\text { helping others } \\
\text { comply (Rs) }\end{array}$ & 147 & 510 & 797 & 1591 & 750 & 1088 \\
\hline $\begin{array}{l}\text { Effective tax rate + } \\
\text { total legal CC }(\% \\
\text { Income })\end{array}$ & N.A. & 4.82 & 9.49 & 13.95 & 23.50 & 22.75 \\
\hline $\begin{array}{l}\text { Tax saved as a \% of } \\
\text { tax paid }\end{array}$ & 9.56 & 66.66 & 52.24 & 22.84 & 17.21 & 9.44 \\
\hline
\end{tabular}


Table 22: Estimates of Compliance Costs as a Percentage of Gross Income by Range of Income: Non-Salaried Respondents

\begin{tabular}{|c|c|c|c|c|c|c|}
\hline $\begin{array}{l}\text { Range-wise number } \\
\text { of respondents }\end{array}$ & 2 & 15 & 11 & 5 & 1 & 3 \\
\hline $\begin{array}{l}\text { Total number of } \\
\text { respondents }=37\end{array}$ & $\begin{array}{l}\text { Rs } \\
50,000 \text { or } \\
\text { less }\end{array}$ & $\begin{array}{l}\text { Rs } 50-100 \\
\text { thousand }\end{array}$ & $\begin{array}{l}\text { Rs 100- } \\
200 \\
\text { thousand }\end{array}$ & $\begin{array}{l}\text { Rs 200- } \\
300 \\
\text { thousand }\end{array}$ & $\begin{array}{l}\text { Rs 300- } \\
400 \\
\text { thousand }\end{array}$ & $\begin{array}{l}\text { Rs } 4,00,000 \\
\text { and above }\end{array}$ \\
\hline Time spent & 1.64 & 2.36 & 9.19 & 1.14 & 0.00 & 1.57 \\
\hline Money spent & 1.23 & 3.99 & 4.81 & 13.79 & N.A. & 4.19 \\
\hline Bribes paid & N.A. & 0.37 & 0.00 & 17.34 & N.A. & 7.18 \\
\hline $\begin{array}{l}\text { Legal (time plus } \\
\text { money) compliance } \\
\text { costs }\end{array}$ & 2.87 & 6.35 & 14.01 & 14.93 & N.A. & 5.76 \\
\hline $\begin{array}{l}\text { Legal + bribe } \\
\text { compliance costs }\end{array}$ & N.A. & 6.72 & 14.01 & 32.26 & N.A. & 12.94 \\
\hline \multicolumn{7}{|c|}{ Memo Items } \\
\hline $\begin{array}{l}\text { Legal + bribe } \\
\text { compliance costs (as } \\
\text { a percentage of tax } \\
\text { paid) }\end{array}$ & N.A. & 337.54 & 183.66 & 223.49 & N.A. & 42.59 \\
\hline $\begin{array}{l}\text { Legal + bribe } \\
\text { compliance costs (in } \\
\text { Rs) }\end{array}$ & N.A. & 4870 & 21490 & 78459 & N.A. & 265847 \\
\hline $\begin{array}{l}\text { Value of time spent } \\
\text { helping others } \\
\text { comply (in Rs) }\end{array}$ & 156 & 109 & 555 & 58 & 226 & 478 \\
\hline $\begin{array}{l}\text { Effective tax rate + } \\
\text { total legal CC }(\% \\
\text { income })\end{array}$ & 2.87 & 7.93 & 23.11 & 29.65 & N.A. & 35.02 \\
\hline $\begin{array}{l}\text { Tax saved as a \% of } \\
\text { tax paid }\end{array}$ & N.A. & 183.89 & 63.48 & 26.02 & 13.16 & 0.55 \\
\hline
\end{tabular}

Note: N.A: No data available or not applicable 
Table 23: Indicators of Vertical Equity

\begin{tabular}{lccc}
\hline & Gross income & $\begin{array}{c}\text { Legal compliance } \\
\text { costs }\end{array}$ & $\begin{array}{c}\text { Legal+bribe } \\
\text { compliance costs }\end{array}$ \\
\hline Gini coefficient & 0.147 & 0.140 & 0.124 \\
Gini of after compliance & ---- & 0.147 & 0.148 \\
cost income & --- & -0.007 & -0.024 \\
Kakwani's Index & & & \\
\hline
\end{tabular}

Table 24: Costs of Complying With Tax Deducted at Sources (TDS): A Case Study

(in rupees per annum)

A. Variable costs per employee subject to TDS

1. Staff costs related to completing and submitting TDS

11,666

returns

2. Staff cost to complete and submit Form 16A for

1,276

employees

3. Computer costs for completing and submitting TDS $\quad 10,007$

returns

4. Photocopying, postal and fax expenses. $\quad 5,000$

Total variable costs

27,949

B. Fixed costs

5. Travel and conveyance $\quad 1,200$

6. Office space at market rental value, general supplies, $\quad 72,308$

stationery

7. Purchase of tax publications and journals $\quad 1,000$

8. Cost of tax advisor/CAs $\quad 3,000$

Total fixed costs $\quad 77,508$

Total costs of compliance: TDS $\quad 1,05,548$

Total income tax paid (April'2000-March'2001) 892,768

Compliance costs of TDS as a percentage of Total $\quad 11.81$

income tax paid

${ }^{43}$ Kakwani's index of progressivity is the difference between the Gini index of compliance costs incurred and net-of-compliance-cost-income. 
Table 25: Fees for Representation Charged by a Firm of Chartered Accountants

\begin{tabular}{lcc}
\hline & $\begin{array}{c}\text { Non-business } \\
\text { individuals }\end{array}$ & $\begin{array}{c}\text { Individuals } \\
\text { carrying on } \\
\text { business or } \\
\text { profession }\end{array}$ \\
\hline $\begin{array}{l}\text { Appeals before Commissioner (Appeals) } \\
\begin{array}{l}\text { Appeals before Income Tax Appellate } \\
\text { Tribunal (ITAT) }\end{array}\end{array}$ & $\begin{array}{l}\text { Rs. } 1500 \\
\text { Rs. } 3500\end{array}$ & $\begin{array}{l}\text { Rs. } 3500 \\
\text { Rs. } 5000\end{array}$ \\
\hline
\end{tabular}


Table 26: Appeals Representation Costs: Crude Estimates

\begin{tabular}{|c|c|c|c|c|c|}
\hline & $\begin{array}{c}2000- \\
2001\end{array}$ & $1999-00$ & $1998-99$ & 1997-98 & $1996-97$ \\
\hline $\begin{array}{l}\text { Appeals for disposal by Commissioners } \\
\text { (Appeals) }\end{array}$ & -- & $2,97,225$ & $2,98,837$ & $2,96,484$ & $3,30,953$ \\
\hline Appeals for disposal by the ITAT & -- & $1,16,639$ & $1,22,247$ & $1,35,246$ & $1,38,952$ \\
\hline $\begin{array}{l}\text { Representation costs of salaried taxpayers } \\
(5 \% \text { of appeals at each level) (Rs. lakh) }\end{array}$ & -- & 217 & 237 & 245 & 265 \\
\hline $\begin{array}{l}\text { Representation cost of non-salaried (95\% of } \\
\text { appeals at each level) (Rs. lakh) }\end{array}$ & -- & 8,200 & 9,028 & 9,237 & 10,092 \\
\hline Total representation costs & -- & 8,417 & 9,265 & 9,482 & 10,357 \\
\hline $\begin{array}{l}\text { Appeal costs as a percentage of previous } \\
\text { year costs }\end{array}$ & 0.93 & 0.91 & 0.98 & 0.92 & -- \\
\hline $\begin{array}{l}\text { Projected appeal costs for } 2000-2001 \text { (Rs } \\
\text { lakh) }\end{array}$ & 7859 & -- & -- & -- & -- \\
\hline
\end{tabular}

Note: Prior to 1998-99, low demand appeals below Rs. 5 lakh were made to Deputy Commissioners (Appeals)

Source of appeals data: CAG (various years) 
Table 27: Aggregate Compliance Cost Estimates for Components Covered in the Survey

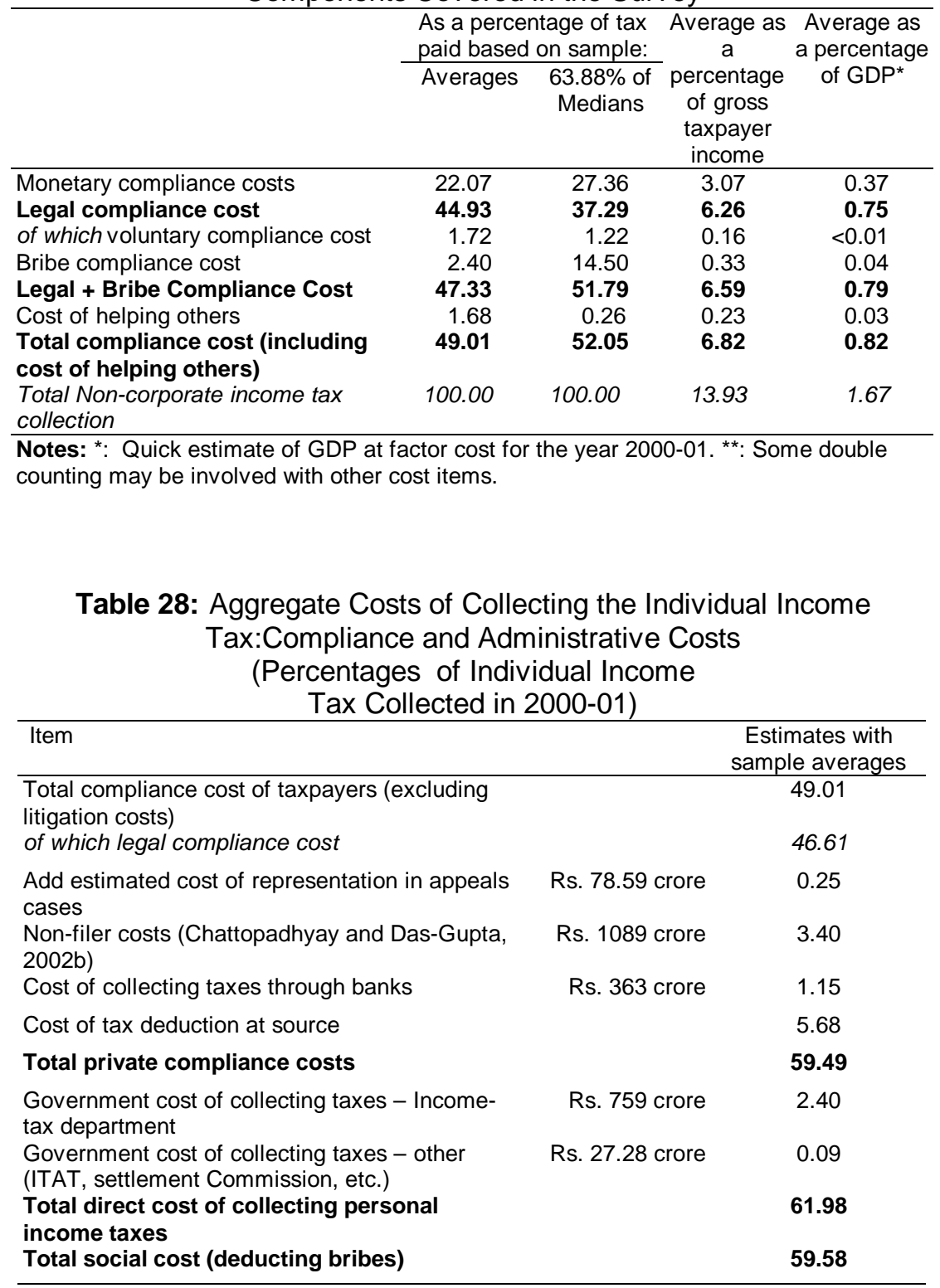




\section{Annex}

\section{Methodology}

The pre-test area was largely restricted to South Delhi to persons with whom canvassers had earlier dealings, such as shopkeepers, colleagues and relations though some questionnaires were administered in other areas and to complete strangers. 50 questionnaires for individuals were canvassed in two pre-survey rounds. Canvassers were asked to (a) administer the questionnaire as if for the final study but also (b) ask respondents about their reactions to different questions and the questionnaire. Instead of a pre-survey, for a separate questionnaire for tax professionals, a focus group meeting (with the BCAS and the CITP, Mumbai) was preferred.

A stratified random sample design, with stratification by the only useful criterion, location, was initially planned and names and addresses of individual taxpayers were obtained from a large government data base. Given incomplete or incorrect addresses only 5435 of the 10,234 addresses could ultimately be used for mailing of questionnaires and reminders. Only 132 responses were received (100 from salary earners, 28 from self-employed and 4 unspecified) of which 10 (7 from the salaried) had to be discarded. Since, an examination of questionnaires made it clear that unspecified responses were not from salaried individuals they are included with the non-salaried. To increase the sample, where questions were similar, pre-survey respondents were added to the sample after statistical tests of differences in means or the significance of dummy variables in regression exercises (reported in Chattopadhyay and Das-Gupta, 2002), confirmed no significant difference for most items surveyed between the pre-survey and the mailed final survey. The important exception to this is discussed below. From tax professionals, only 1 response was received to the 120 questionnaires distributed through associations of tax professionals. The ultimate questionnaire distribution and response rates are in Table A1. 
Table A1: Questionnaires sent and responses received

\begin{tabular}{|c|c|c|}
\hline & Numbers & o of initial sample \\
\hline \multicolumn{3}{|l|}{ Mailing and canvassing details } \\
\hline Canvassed during two pre-surveys & 50 & Not Applicable \\
\hline $\begin{array}{l}\text { Addresses received from government } \\
\text { data base }\end{array}$ & 10,234 & 97.80 \\
\hline of which addresses found incomplete & 4,700 & 44.92 \\
\hline Net received & 5,534 & 52.89 \\
\hline Add addresses from other sources & 230 & 2.20 \\
\hline $\begin{array}{l}\text { of which questionnaires mailed to } \\
\text { addresses obtained from elsewhere }\end{array}$ & 100 & 0.96 \\
\hline of which responses received & 3 & \\
\hline $\begin{array}{l}\text { Questionnaires hand delivered after } \\
\text { individual contact }\end{array}$ & 130 & 1.24 \\
\hline of which responses received & \multicolumn{2}{|c|}{$\begin{array}{l}\text { Not ascertainable as business reply } \\
\text { envelopes were identical to those } \\
\text { used in the general mailing. }\end{array}$} \\
\hline Total addresses available & 5,764 & 55.08 \\
\hline $\begin{array}{l}\text { Number of questionnaires mailed or hand } \\
\text { delivered }\end{array}$ & 5,530 & 52.85 \\
\hline $\begin{array}{l}\text { Number not deliverable by post offices } \\
\text { due to incorrect addresses or inability to } \\
\text { trace addressees }\end{array}$ & 295 & 2.82 \\
\hline Memo & & \\
\hline $\begin{array}{l}120 \text { tax professional questionnaires } \\
\text { mailed to tax professionals }\end{array}$ & \multicolumn{2}{|c|}{1 response received } \\
\hline \multicolumn{3}{|l|}{ Details of responses } \\
\hline & Salaried & Self-employed \\
\hline Responses received & 100 & 32 \\
\hline Responses discarded & 7 & 3 \\
\hline $\begin{array}{l}\text { Total sample for questions not asked in } \\
\text { pre-surveys }\end{array}$ & 93 & 29 \\
\hline Gross response rate (\%) & \multicolumn{2}{|c|}{2.36} \\
\hline Net response rate (\%) & \multicolumn{2}{|c|}{2.17} \\
\hline $\begin{array}{l}\text { Add pre-survey canvassed } \\
\text { "questionnaires }\end{array}$ & 29 & 21 \\
\hline $\begin{array}{l}\text { Total sample for common pre-survey and } \\
\text { final survey questions }\end{array}$ & 122 & 50 \\
\hline
\end{tabular}

The important exception where differences did show up between the canvassed pre survey and the mailed final survey this was questions relating to bribes (Table A2). So if ascertaining bribe costs is important, anonymous mailed surveys may have significant advantages over faceto-face canvassed surveys despite a low response rate, data quality and respondent bias. 
Table A2: Response to Questions on Bribe Payment Pretests (Canvassed) Versus

Final (Mailed) Sample

\begin{tabular}{|c|c|c|c|c|}
\hline & \multicolumn{2}{|c|}{ Pre Tests } & \multicolumn{2}{|c|}{ Final Sample } \\
\hline & Salary & Non-Salary & Salary & Non-Salary \\
\hline Percentage admitting to Bribing & 4.8 & 7.7 & 22.7 & 42.4 \\
\hline Percentage senying bribing & 81.0 & 69.2 & 41.2 & 21.2 \\
\hline Percentage not commenting & 14.3 & 23.1 & 36.1 & 36.4 \\
\hline Response rate (\%) & 100.0 & 100.0 & 96.0 & 46.5 \\
\hline $\begin{array}{l}\text { Potential maximum bribe } \\
\text { payers }(\%)\end{array}$ & 19.0 & 30.8 & 58.8 & 78.8 \\
\hline
\end{tabular}

\section{Areas Covered in Questionnaires}

Areas covered in questionnaires included:

- Fiscal knowledge and attitudes: Around 10 questions covering information on how tax returns were completed; reasons for use of advisors,; time spent helping others; self assessed knowledge of the income tax; and assessment of benefits from government services and whether income taxes were high, about right or too low.

- Reported compliance costs: 5 questions dealing with time spent and its valuation; compliance related expenditure and benefits from compliance activities, if any.

- Taxes, income and administration procedures: 10 questions covering tax payments, tax saving, and whether the taxpayer was facing scrutiny or appeals.

- Tax evasion, bribe payment and benefits from bribes: 5 questions in all.

- Background information including education, sex, age, income and occupation.

- Open ended questions on how high respondents felt compliance costs were and if they wished to call attention to any other matters.

\section{Sample Versus Population Distributions}

Sampling bias is a serious problem in this study. (a) The most serious is the omission of non-filers. (b) Non-response bias also has partly unknown characteristics. Comparison with Income-tax fepartment data suggests high income taxpayers are over-represented in the sample. However, given inadequate data from the department on 
taxpayers classified by (gross) income, the exact nature of this bias cannot be determined. (c) It is likely that there is an over-representation of highly educated taxpayers, though this cannot be verified.

Official statistics on the income distribution of income tax payers provide limited and out-of-date. The latest available data, reported in CAG (2001), consists of (a) taxpayer distributions by range of taxable income for 4 broad income groups for 1999-2000 and (b) sample based estimates from the All India Income Tax Statistics (AIITS) of distribution by 10 ranges of taxable income for 1996-97, including information on gross income, taxable income and tax paid for taxpayers. The population distribution was estimated after inflating all income figures and ranges to 2000-01 rupees, using the Consumer Price Index for Urban Non-Manual Employees $(1985=100)$ and then merging the 1999-2000 and 1996-97 distributions. No attempt was made to project taxpayer growth to 200001 . For sample respondents, pre-survey data was inflated by the price index for one year, since it was conducted in 2000-01. The pre-survey and final survey data were then merged and grouped by ranges of taxable income. Comparing sample and "population", the sample is biased towards high income taxpayers, except for the absence of respondents in the second highest income range. Details are in Table A3. 
Table A3: Cumulative Distribution of Assessees: Population Versus Study Sample

\begin{tabular}{|c|c|c|c|c|c|c|c|c|c|c|}
\hline \multirow{2}{*}{$\begin{array}{c}\text { Income range in } \\
\text { 1996-97 Rupees } \\
\text { '000 }\end{array}$} & \multirow{2}{*}{$\begin{array}{c}\text { Income range in } \\
2000-01 \text { Rupees } \\
\text { '000 }\end{array}$} & \multicolumn{3}{|c|}{$\begin{array}{l}\text { "Population" distribution of } \\
\text { assessees in 1999-00 }\end{array}$} & \multicolumn{3}{|c|}{$\begin{array}{l}\text { Sample distribution of } \\
\text { respondents }\end{array}$} & \multicolumn{3}{|c|}{ Sample minus population } \\
\hline & & All & Salaried & $\begin{array}{r}\text { Non- } \\
\text { Salaried } \\
\end{array}$ & All & Salaried & $\begin{array}{r}\text { Non- } \\
\text { Salaried } \\
\end{array}$ & All & Salaried & $\begin{array}{r}\text { Non- } \\
\text { Salaried }\end{array}$ \\
\hline $0-40$ & $0-52.44$ & 12.73 & 3.94 & 14.71 & 3.23 & 2.54 & 5.41 & -9.51 & -1.40 & -9.31 \\
\hline $40-50$ & 52.44-65.55 & 41.97 & 16.45 & 47.72 & 10.32 & 5.93 & 24.32 & -31.65 & -10.52 & -23.39 \\
\hline $50-100$ & $65.55-131.1$ & 83.90 & 79.99 & 84.78 & 43.23 & 41.53 & 48.65 & -40.68 & -38.46 & -36.14 \\
\hline $100-200$ & 131.1-262.19 & 97.43 & 99.85 & 96.88 & 89.03 & 89.83 & 86.49 & -8.39 & -10.02 & -10.39 \\
\hline $200-300$ & $262.19-393.29$ & 97.76 & 99.91 & 97.28 & 94.84 & 95.76 & 91.89 & -2.92 & -4.15 & -5.39 \\
\hline $300-400$ & $393.29-524.38$ & 97.92 & 99.94 & 97.47 & 96.13 & 97.46 & 91.89 & -1.79 & -2.48 & -5.58 \\
\hline $400-500$ & $524.38-655.48$ & 98.56 & 99.96 & 98.25 & 98.06 & 99.15 & 94.59 & -0.50 & -0.81 & -3.66 \\
\hline $500-1000$ & $655.48-1310.95$ & 99.87 & 99.98 & 99.84 & 98.06 & 99.15 & 94.59 & -1.80 & -0.83 & -5.25 \\
\hline $1000 \&$ above & $\begin{array}{l}1310.95 \& \\
\text { above }\end{array}$ & 100.00 & 100.00 & 100.00 & 100.00 & 100.00 & 100.00 & 0.00 & 0.00 & 0.00 \\
\hline
\end{tabular}




\section{Aggregation Methodology}

Assuming that proportions of assessees in each real income group remains unaltered, distributions of salaried and non-salaried taxpayers were derived, ensuring that the total number of assessees matched the CAG total from the merged taxpayer distribution described above Where necessary, linear interpolation was used. The computations are summarised in Tables A4 and A5.

Table A4: Estimating Gross Income from AlITS and CAG Data

\begin{tabular}{|c|c|c|c|c|c|c|}
\hline $\begin{array}{l}\text { AllTS returne } \\
\text { range in } 2000\end{array}$ & $\begin{array}{l}\text { income } \\
1 \text { Rupees }\end{array}$ & \multirow[t]{2}{*}{$\begin{array}{c}\text { Gross } \\
\text { income per } \\
\text { capita } \\
\text { (AlITS, in } \\
2000-01 \\
\text { Rs) } \\
46,961\end{array}$} & \multirow[t]{2}{*}{$\begin{array}{c}\text { Income } \\
\text { returned } \\
\text { per capita } \\
\text { (AlITS in } \\
2000-01 \\
\text { Rs) } \\
32,034\end{array}$} & \multirow[t]{2}{*}{$\begin{array}{c}\text { Final } \\
\text { assessee } \\
\text { estimate to } \\
\text { match CAG } \\
\text { total } \\
25,07,257\end{array}$} & \multirow[t]{2}{*}{$\begin{array}{r}\begin{array}{c}\% \text { of } \\
\text { salaried } \\
\text { taxpayers }\end{array} \\
\\
5.66\end{array}$} & \multirow[t]{2}{*}{$\begin{array}{c}\text { Gross income } \\
\text { of all } \\
\text { assessees } \\
\left(\text { Rs } 10^{5}\right) \\
\\
1177444\end{array}$} \\
\hline 0 & 52438 & & & & & \\
\hline 52438 & 65548 & 60,208 & 57,807 & $57,57,791$ & 7.82 & 3466647 \\
\hline 65548 & 131095 & 99,465 & 90,841 & $82,58,311$ & 27.69 & 8214121 \\
\hline 131095 & 210795 & $1,97,191$ & $1,73,038$ & $23,10,135$ & 26.84 & 4555376 \\
\hline 210795 & 262191 & $1,97,192$ & $1,73,038$ & $3,41,221$ & 0.27 & 672860 \\
\hline 262191 & 393286 & $3,68,156$ & $3,16,748$ & 64,327 & 3.61 & 236825 \\
\hline 393286 & 524382 & $5,13,789$ & $4,48,551$ & 30,184 & 2.58 & 155081 \\
\hline 524382 & 655477 & $6,41,545$ & $5,85,363$ & 15,406 & 5.05 & 98839 \\
\hline 655477 & 1053977 & $10,07,756$ & $9,02,789$ & $2,35,603$ & 0.29 & 2374304 \\
\hline 1053977 & 1310954 & $10,07,756$ & $9,02,789$ & 20,879 & 2.12 & 210409 \\
\hline \multirow{2}{*}{\multicolumn{2}{|c|}{$\begin{array}{c}1310954 \text { and above } \\
\text { Total }\end{array}$}} & $59,87,320$ & $52,53,364$ & 26,282 & 2.90 & 1573572 \\
\hline & & & & $1,95,67,396$ & 17.91 & $227,354,78$ \\
\hline
\end{tabular}

Table A5: Estimating the Total Number of Assesses from

AlITS and CAG Data

\begin{tabular}{ccrrrr}
\hline \multirow{2}{*}{$\begin{array}{c}\text { AllTS returned income } \\
\text { range in 2000-01 Rupees }\end{array}$} & \multicolumn{2}{c}{$\begin{array}{c}\text { Number of assessees: AllTS } \\
(1996-97)\end{array}$} & $\begin{array}{c}\text { AllTS: 1996-97 figures inflated } \\
\text { to match CAG }\end{array}$ \\
\cline { 3 - 6 } & & Non salary & \multicolumn{1}{c}{ Salary } & Non salary & \multicolumn{1}{c}{ Salary } \\
\hline 0 & 52438 & 1017703 & 65646 & 2200566 & 141946 \\
52438 & 65548 & 2279737 & 208113 & 4929446 & 450000 \\
65548 & 131095 & 2510850 & 1057436 & 5429179 & 2286480 \\
131095 & 210795 & 1355162 & 286701 & 2930249 & 619930 \\
210795 & 262191 & 33756 & 421 & 72990 & 910 \\
262191 & 393286 & 86100 & 1073 & 186174 & 2321 \\
393286 & 524382 & 56579 & 360 & 122340 & 778 \\
524382 & 655477 & 28702 & 360 & 62062 & 778
\end{tabular}


Table A5: Estimating the Total Number of Assesses from AIITS and CAG Data

\begin{tabular}{|c|c|c|c|c|c|}
\hline \multicolumn{2}{|c|}{$\begin{array}{l}\text { AllTS returned income } \\
\text { range in 2000-01 Rupees }\end{array}$} & \multicolumn{2}{|c|}{$\begin{array}{c}\text { Number of assessees: AlITS } \\
(1996-97)\end{array}$} & \multicolumn{2}{|c|}{$\begin{array}{c}\text { AlITS: } 1996-97 \text { figures inflated } \\
\text { to match CAG }\end{array}$} \\
\hline & & Non salary & Salary & Non salary & Salary \\
\hline 655477 & 1053977 & 24392 & 317 & 52742 & 685 \\
\hline 1053977 & 1310954 & 15729 & 204 & 34011 & 442 \\
\hline \multicolumn{2}{|c|}{1310954 and above } & 19705 & 352 & 42608 & 761 \\
\hline \multirow{2}{*}{\multicolumn{2}{|c|}{$\begin{array}{c}\text { Total } \\
\text { Salary plus Non-Salary }\end{array}$}} & 7428415 & 1620983 & 16062367 & 3505031 \\
\hline & & 90 & & 195673 & \\
\hline
\end{tabular}

Average compliance costs for each income group were then computed. In case of missing data, cells the minimum value across all the income groups of compliance costs for the particular category was conservatively assumed. Total legal compliance costs were derived using a two-step procedure. First, by adding time and money compliance costs total legal costs were obtained. Due to missing observations, averages for subcategories over available observations, exceeded totals. So individual averages were scaled down proportionately to add up to totals.

\section{Individual Income Tax, Surcharge and Standard Deduction} Rates: 1999-00 and 2000-01

Rates of income-tax for the financial year (FY) 2000-2001 (Assessment year 2001-02) are in Table A6. Table A7 gives rates of surcharge on tax payable for FY 2000-2001 and Table A8 gives rates of standard deduction for FY 2000-01.

Table A6: Rates of Income Tax for Individuals:

Assessment year 2000-2001 \& 2001-2002

\begin{tabular}{ll}
\hline Net income range & Rates of income-tax \\
\hline Up to Rs. 50,000 & Nil \\
Rs. $50,000-$ Rs. 60,000 & $\begin{array}{l}10 \text { per cent of the amount by which the total income } \\
\text { exceeds Rs. 50,000; }\end{array}$ \\
Rs. $60,000-$ Rs. $1,50,000$ & $\begin{array}{l}\text { Rs. } 1,000 \text { plus } 20 \text { per cent of the total income in excess of } \\
\text { Rs. } 60,000 ;\end{array}$ \\
Rs. $1,50,000$ and above & $\begin{array}{l}\text { Rs. } 19,000 \text { plus } 30 \text { per cent of the total income in excess of } \\
\text { Rs. } 1,50,000 .\end{array}$ \\
\hline
\end{tabular}


Table A7: Surcharge in Financial Year 2000-2001: Assessment year 2001-2002

\begin{tabular}{llll}
\hline Income slab & $\begin{array}{l}\text { Surcharge } \\
\text { for AY } \\
2000-2001\end{array}$ & $\begin{array}{l}\text { Surcharge for } \\
\text { AY 2001-2002 }\end{array}$ & $\begin{array}{l}\text { Marginal relief } \\
\text { for AY 2001- } \\
2002\end{array}$ \\
\hline $\begin{array}{l}\text { Total Income upto 60,000/- } \\
\text { NIL }\end{array}$ & NIL & NIL \\
$\begin{array}{l}\text { Total Income exceeding Rs 60,000/- } \\
\text { but not exceeding Rs 1,50,000/-. }\end{array}$ & $10 \%$ & $10 \%$ & Note 1 \\
$\begin{array}{l}\text { Total Income exceeding Rs 1,50,000/- } \\
\text { To\% }\end{array}$ & $15 \%$ & Note 2
\end{tabular}

Note 1: If net income exceeds Rs. 60,000 total income tax and surcharge payable shall not exceed income tax on net income of Rs.60,000 (i.e. Rs. 1,000 ) by more than the amount of income that exceeds Rs. 60,000 .

Note 2: If net income exceeds Rs. 150,000 total income tax and surcharge shall not exceed income tax on net income of Rs. 150,000 (i.e. Rs. 20,900) by more than the amount of income that exceeds Rs. 150,000.

* Surcharge is payable after calculating rebate $u / s, 88$ and 88.B.

Table A8: Rates of Standard Deduction from Salary Income for Financial Year 2000-2001

(Assessment year 2001-2002)

\begin{tabular}{ll}
\hline Gross salary income below Rs 100,000 & $\begin{array}{l}\text { One-third of gross income with a ceiling } \\
\text { of Rs 25,000 }\end{array}$ \\
$\begin{array}{l}\text { Gross salary income above Rs } 100,000 \\
\text { Rs to Rs } 500,000\end{array}$ & Nil \\
\hline
\end{tabular}

\section{Income Tax Knowledge of Respondents}

In the limited responses received, salary earners reported better knowledge of the income tax than the non-salaried (Table A9).

Table A9: Knowledge About the Income Tax

\begin{tabular}{|c|c|c|c|c|c|c|}
\hline & \multicolumn{3}{|c|}{ Number of responses } & \multicolumn{3}{|c|}{ Percentage of total responses } \\
\hline & $\begin{array}{c}\text { Non } \\
\text { salaried }\end{array}$ & Salaried & All & $\begin{array}{c}\text { Non } \\
\text { salaried }\end{array}$ & Salaried & All \\
\hline Excellent & 0 & 1 & 1 & 0.0 & 2.9 & 1.9 \\
\hline Good & 0 & 5 & 5 & 0.0 & 14.3 & 9.6 \\
\hline Average & 8 & 17 & 25 & 47.1 & 48.6 & 48.1 \\
\hline Fair & 3 & 7 & 10 & 17.6 & 20.0 & 19.2 \\
\hline Poor & 4 & 3 & 7 & 23.5 & 8.6 & 13.5 \\
\hline No knowledge & 2 & 2 & 4 & 11.8 & 5.7 & 7.7 \\
\hline Total responses & 17 & 35 & 52 & 100.0 & 100.0 & 100.0 \\
\hline $\begin{array}{l}\text { Total questionnaires } \\
\text { where question asked }\end{array}$ & 23 & 41 & 74 & N.A. & N.A. & N.A. \\
\hline
\end{tabular}




\section{Distribution of Compliance Costs in the Sample}

Table A10: Compliance Costs in Hours and Rupees

\begin{tabular}{|c|c|c|c|c|c|c|}
\hline Group & $\begin{array}{l}\text { Total } \\
\text { time } \\
\text { spent } \\
\text { (hours) }\end{array}$ & $\begin{array}{l}\text { Time } \\
\text { compliance } \\
\text { costs (Rs) }\end{array}$ & $\begin{array}{l}\text { Money } \\
\text { compliance } \\
\text { costs (Rs) }\end{array}$ & $\begin{array}{l}\text { Bribes } \\
\text { (Rs) }\end{array}$ & $\begin{array}{l}\text { Legal } \\
\text { compliance } \\
\text { costs (Rs) }\end{array}$ & $\begin{array}{l}\text { Third party } \\
\text { time cost of } \\
\text { helping } \\
\text { others (Rs) }\end{array}$ \\
\hline \multicolumn{7}{|l|}{ Salaried respondents } \\
\hline Zero & 6 & 6 & 24 & 0 & 0 & 28 \\
\hline Low & 41 & 43 & 44 & 6 & 61 & 9 \\
\hline Medium & 18 & 20 & 14 & 0 & 15 & 11 \\
\hline High & 50 & 46 & 35 & 6 & 38 & 47 \\
\hline Median & 11.5 & 858 & 250 & 750 & 1296 & 200 \\
\hline Maximum & 420 & 24840 & 14360 & 7500 & 28490 & 7800 \\
\hline Responses & 115 & 115 & 117 & 12 & 114 & 95 \\
\hline \multicolumn{7}{|c|}{ Non-salaried respondents } \\
\hline Zero & 4 & 4 & 1 & 0 & 0 & 13 \\
\hline Low & 8 & 9 & 3 & 2 & 7 & 3 \\
\hline Medium & 4 & 2 & 4 & 0 & 5 & 2 \\
\hline High & 17 & 18 & 34 & 2 & 29 & 10 \\
\hline Median & 17 & 1485 & 3081 & 21330 & 5251 & 57 \\
\hline Maximum & 843 & 632400 & 143341 & 147557 & 666128 & 4743 \\
\hline Responses & 33 & 33 & 42 & 4 & 41 & 28 \\
\hline \multicolumn{7}{|c|}{$\begin{array}{l}\text { Criteria for classification } \\
\text { (Low: <0.75 combined median; Medium: 0.75-1.25 combined median; High: }>1.25 \text { combined } \\
\text { median) }\end{array}$} \\
\hline 0.75 combined median & 9 & 711.38 & 375.00 & 562.50 & 1338.00 & 129.00 \\
\hline 1.25 combined median & 15 & 1185.63 & 625.00 & 937.50 & 2230.00 & 215.00 \\
\hline
\end{tabular}


Table A11: Compliance Costs and Tax Saving as a

\begin{tabular}{|c|c|c|c|c|c|c|c|}
\hline Group & $\begin{array}{l}\text { Time } \\
\text { compliance } \\
\text { costs }\end{array}$ & $\begin{array}{l}\text { Money } \\
\text { compliance } \\
\text { costs }\end{array}$ & Bribes & $\begin{array}{l}\text { Legal } \\
\text { compliance } \\
\text { costs }\end{array}$ & $\begin{array}{l}\text { Legal } \\
\text { compliance } \\
\text { costs+ } \\
\text { bribes }\end{array}$ & $\begin{array}{l}\text { Tax } \\
\text { saved }\end{array}$ & $\begin{array}{l}\text { Legal } \\
\text { compliance } \\
\text { costs } \\
\text { ( } \% \text { of } \\
\text { gross tax) }\end{array}$ \\
\hline \multicolumn{8}{|c|}{ Salaried respondents } \\
\hline Zero & 1 & 16 & 0 & 0 & 0 & 32 & 0 \\
\hline Low & 44 & 33 & 6 & 49 & 49 & 12 & 53 \\
\hline Medium & 8 & 7 & 2 & 13 & 12 & 11 & 17 \\
\hline High & 41 & 36 & 3 & 32 & 33 & 63 & 41 \\
\hline Median & 7.1 & 1.6 & 5.6 & 12.1 & 12.6 & 36.2 & 7.3 \\
\hline Maximum & 897 & 973 & 41 & 1870 & 1870 & 100 & 361 \\
\hline Respondents & 94 & 92 & 11 & 94 & 94 & 118 & 111 \\
\hline \multicolumn{8}{|c|}{ Non-salaried respondents } \\
\hline Zero & 3 & 1 & 0 & 0 & 0 & 24 & 0 \\
\hline Low & 3 & 0 & 0 & 2 & 2 & 4 & 5 \\
\hline Medium & 3 & 2 & 0 & 1 & 1 & 3 & 1 \\
\hline High & 13 & 20 & 3 & 19 & 19 & 9 & 18 \\
\hline Median & 17 & 52 & 25 & 103 & 131 & 0.0 & 71 \\
\hline Maximum & 480 & 1654 & 100 & 1717 & 1717 & 100 & 1717 \\
\hline Total & 22 & 23 & 3 & 22 & 22 & 40 & 24 \\
\hline \multicolumn{8}{|c|}{$\begin{array}{l}\text { Criteria for classification } \\
\text { (Low: <0.75 combined median; Medium: } 0.75-1.25 \text { combined median; High: }>1.25 \text { combined } \\
\text { median) }\end{array}$} \\
\hline $\begin{array}{l}0.75 \text { combined } \\
\text { median }\end{array}$ & 6.59 & 2.34 & 6.03 & 12.99 & 13.80 & 18.61 & 6.66 \\
\hline $\begin{array}{l}1.25 \text { combined } \\
\text { median }\end{array}$ & 10.99 & 3.91 & 10.05 & 21.66 & 23.00 & 31.02 & 11.11 \\
\hline
\end{tabular}


Table A12: Compliance Costs as a Percentage of Gross Income

\begin{tabular}{|c|c|c|c|c|c|}
\hline Group & $\begin{array}{l}\text { Time } \\
\text { compliance } \\
\text { costs }\end{array}$ & $\begin{array}{l}\text { Money } \\
\text { compliance } \\
\text { costs }\end{array}$ & Bribes & $\begin{array}{l}\text { Legal } \\
\text { compliance } \\
\text { costs }\end{array}$ & $\begin{array}{l}\text { Legal } \\
\text { compliance } \\
\text { costs + bribes }\end{array}$ \\
\hline \multicolumn{6}{|l|}{ Salary } \\
\hline Zero & 6 & 21 & 0 & 0 & 0 \\
\hline Low & 46 & 41 & 6 & 54 & 53 \\
\hline Medium & 14 & 14 & 2 & 20 & 20 \\
\hline High & 49 & 37 & 4 & 39 & 40 \\
\hline Median & 0.49 & 0.13 & 0.37 & 0.84 & 0.87 \\
\hline Maximum & 17.0 & 11.3 & 3.8 & 21.3 & 21.3 \\
\hline Respondents & 115 & 113 & 12 & 113 & 113 \\
\hline \multicolumn{6}{|l|}{ Non-Salary } \\
\hline Zero & 4 & 1 & 0 & 0 & 0 \\
\hline Low & 8 & 2 & 1 & 3 & 2 \\
\hline Medium & 3 & 1 & 0 & 2 & 4 \\
\hline High & 16 & 27 & 3 & 25 & 24 \\
\hline Median & 1 & 3 & 3 & 8 & 8 \\
\hline Maximum & 44 & 55 & 19 & 57 & 57 \\
\hline Respondents & 31 & 31 & 4 & 30 & 30 \\
\hline \multicolumn{6}{|c|}{$\begin{array}{l}\text { Criteria for classification(Low: }<0.75 \text { combined median; Medium: } 0.75-1.25 \\
\text { combined median; High: }>1.25 \text { combined median) }\end{array}$} \\
\hline $\begin{array}{l}0.75 \text { combined } \\
\text { median }\end{array}$ & 0.41 & 0.19 & 0.37 & 0.78 & 0.80 \\
\hline $\begin{array}{l}1.25 \text { combined } \\
\text { median }\end{array}$ & 0.68 & 0.32 & 0.62 & 1.31 & 1.33 \\
\hline
\end{tabular}




\section{References}

Allers, Marteen 1995. "Tax Compliance Costs in the Netherlands" in Cedric Sandford (ed.), Tax Compliance Costs Measurement and Policy. Bath, UK: Fiscal Publications.

Andreoni, James, Brian Erard and Jonathan Feinstein, 1998. "Tax Compliance", Journal of Economic Literature, 36: 818-860.

Atkinson, Anthony and Joseph E. Stiglitz, 1979. Lectures in Public Economics. New York: McGraw-Hill.

Atkinson, Anthony and Nicholas Stern, 1974. "Pigou, Taxation, and Public Goods", Review of Economic Studies, 41: 119-128.

Barbone, et.al., 1999. "Reforming Tax Systems: The World Bank Record in the 1990s", Working Paper 2237, The World Bank, Washington D.C.

Bardsley, Peter 1997. "Simplifying the Tax Law: Some Implications for Small Business", Australian Tax Forum, 13: 91-113.

Bhatnagar, Dheeraj 1997. "Compliance Costs: The Taxpayer's Perspective", Dissertation for the M.Sc. in Fiscal Studies, University of Bath, Bath, U.K.

Binh et.al. 2000. "Tax Compliance Research: Research Methodology and Empirical Evidence from Australia, National Tax Journal, 53: 229251.

Bird, Richard M. 1982. "The Costs of Collecting Taxes: Preliminary Reflections on the Uses and Limits of Cost Studies", Canadian Tax Journal, 30: 860-65.

Blumenthal, Marsha and Joel Slemrod 1992. " The Compliance Cost of the U.S. Individual Income Tax System: A Second Look After Tax Reform", National Tax Journal, 45: 185-202. 
1995. "Recent Tax Compliance Cost Research in the United States" in Cedric Sandford (ed.), Tax Compliance Costs Measurement and Policy. Bath, UK: Fiscal Publications.

Boucher, Trevor 1986. "Self-Assessment of Income Tax", Australian Tax Forum, 3: 45-53.

Boucher, Trevor 1991. "Tax Simplification - Some Different Dimensions", Address to the Monash University Law School Foundation, Melbourne (3 September).

Chattopadhyay, S. and A. Das-Gupta 2002. "The Compliance Cost of the Personal Income Tax and its Determinants", mimeo, New Delhi: NIPFP. Available at http://www.planingcommission.nic.in/reports.

2002a. " The Income Tax Compliance Cost of Indian Corporations ", mimeo, New Delhi: NIPFP. Available at http://www.planingcommission.nic.in/reports.

---, 2002b. "The Personal Income Tax in India: Compliance Costs and Compliance Behaviour of Taxpayers", mimeo, New Delhi: NIPFP. Available at http://www.planingcommission. nic.in/reports.

Collard, David and Michael Godwin 1999. "Compliance Costs for Employers: UK PAYE and National Insurance, 1995-96", Fiscal Studies. 20: 423-449.

Comptroller and Auditor General (CAG), Government of India 2001. Report of the Comptroller and Auditor General of India for the year ended March, 2000, Union Government (Direct Taxes), No. 12 of 2000. New Delhi: CAG.

Cooper, G.S. 1993. "Themes and Issues in Tax Simplification", Australian Tax Forum, 10: 417-460.

Das-Gupta, Arindam 2002. "Central Tax and Administration Reform in the 1990s" in M. Govinda, Rao (ed.), Development, Poverty and Fiscal Policy - Decentralization of Institutions (Essays in honour of Raja Chelliah). New Delhi: Oxford University Press. 
Das-Gupta, Arindam and Mookherjee, Dilip 1997. 'Design and Enforcement of Personal Income Taxes in India', In Mundle, Sudipto (ed.) Public Finance: Policy Issues for India. New Delhi: Oxford University Press.

1998. Incentives and Institutional Reform in Tax Enforcement', New Delhi: Oxford University Press.

Evans, Chris and Michael Walpole, 1997. "Compliance Costs and Taxation Impact Statements", Australian Tax Forum, 13: 227-274.

Fischer, Lutz 1989. "National Report, Germany", in Studies in International Fiscal Law: Administrative and Compliance Costs of Taxation, Cahiers De Droit Fiscal International, Volume 74b. Rio De Janeiro: International Fiscal Association.

Freidkes, Nahum and Moshe Gavish, 1989. "National Report, Israel", in Studies in International Fiscal Law: Administrative and Compliance Costs of Taxation, Cahiers De Droit Fiscal International, Volume 74b. Rio De Janeiro: International Fiscal Association.

Gerade, Marcel, Pascale Blondiaux, and Carine Vanden Berghe, "National Report, Belgium", Studies in International Fiscal Law: Administrative and Compliance Costs of Taxation, Cahiers De Droit Fiscal International, Volume 74b. Rio De Janeiro: International Fiscal Association.

Glassberg, Barry and Christina Smyth, 1995. "Tax Compliance Costs: the Problems and the Practice - Inland Revenue" in Cedric Sandford (ed.), 'Tax Compliance Costs Measurement and Policy'. Bath, U.K: Fiscal Publications in association with The Institute for Fiscal Studies.

Godwin, Michael, P.J.W. Hardwick and C.T. Sandford, 1983. "PAYE: Costs v Benefits", Accountancy, November: 107-112.

Godwin, Michael 1995. "The Compliance Costs of the United Kingdom Tax System", in Cedric Sandford (ed.), Tax Compliance Costs Measurement and Policy, Bath. U.K: Fiscal Publications in association with The Institute for Fiscal Studies. 
Government of India, Ministry of Finance and Company Affairs 2002. Economic Survey. New Delhi: Government of India Printing Press.

-----, 2002. "Report of the Task Force on Direct Taxes (Kelkar Task Force). New Delhi: Government of India, Ministry of Finance and Company Affairs.

Haig, Robert M. 1935. "The Cost to Business Concerns of Compliance with Tax Laws", Management Review, 24: 323-333.

Harris, I.W. 1989. "National Report, Hong Kong", in Studies in International Fiscal Law: Administrative and Compliance Costs of Taxation, Cahiers De Droit Fiscal International, Volume 74b. Rio De Janeiro: International Fiscal Association.

Hasseldine, John 1995. "Tax Compliance Costs of Major Taxes in Australia" in Cedric Sandford, (ed.), Tax Compliance Costs Measurement and Policy. Bath, U.K.: Fiscal Publications in association with The Institute for Fiscal Studies.

Hite, Peggy A. and Adrian J. Sawyer, 1997. "A Comparison of Compliance Cost Estimates for the Tax System in the United States and New Zealand", International Bureau of Fiscal Documentation, February: 93-97.

Hudson, John and Michael Godwin, 2000. "The Compliance Costs of Collecting Direct Tax in the UK: An Analysis of PAYE and National Insurance", Journal of Public Economics, 77: 29-44.

Imhof, F.W. 1989. "National Report, Netherlands", in Studies in International Fiscal Law: Administrative and Compliance Costs of Taxation, Cahiers De Droit Fiscal International, Volume 74b. Rio De Janeiro: International Fiscal Association.

International Fiscal Association 1989. Studies in International Fiscal Law: Administrative and Compliance Costs of Taxation, Cahiers De Droit Fiscal International, Volume: 74b. Rio de Janeiro: International Fiscal Association. 
James, Simon., Adrian Sawyer, and lan Wallschutzky, 1997. "Tax Simplification - A Tale of Three Countries", Bulletin for International Fiscal Documentation, November: 493-503.

Klepper, S. and D. Nagin, 1989. "The Role of Tax Preparers in Tax Compliance", Policy Sciences, 22:167-94.

Malmer, Hakan 1995. "The Swedish Tax Reform in 1990-1991 and Tax Compliance Costs in Sweden", in Cedric Sandford, (ed.), Tax Compliance Costs Measurement and Policy. Bath, U.K.: Fiscal Publications in association with The Institute for Fiscal Studies.

Matheu, Luis Maria and C.P. Angel Gustavo Secchi, 1989. "National Report, Argentina", in Studies in International Fiscal Law: Administrative and Compliance Costs of Taxation, Cahiers De Droit Fiscal International, Volume 74b. Rio De Janeiro: International Fiscal Association.

McCulloch, S 1992. "Tax compliance costs: Heaviest burden on small firms," Accountant's Journal, 72, November.

McLure, Jr., Charles E. 1989. "The Budget Process and Tax Simplification/Complication", Tax Law Review, 45: 25-96.

Mikesell, John L. 1996. "Federal Individual Income Tax Collection Costs: The Burden of Compliance and Administration", in Richard, W. Lindholm, (ed.) Examination of Basic Weaknesses of Income as the Major Federal Tax Base. New York: Praeger Publishers.

Milgrom, Paul and John Roberts 1992. Economics, Organization and Management. Saddle River, New Jersey: Prentice Hall.

Nicolaissen, Rolf H. 1989. "National Report, Norway", in Studies in International Fiscal Law: Administrative and Compliance Costs of Taxation, Cahiers De Droit Fiscal International, Volume 74b. Rio De Janeiro: International Fiscal Association.

Norrman, Bo and Hakan Malmer, 1989. "National Report, Sweden", in Studies in International Fiscal Law: Administrative and Compliance Costs of Taxation, Cahiers De Droit Fiscal International, Volume 74b. Rio De Janeiro: International Fiscal Association. 
Plamondon, Robert E. and David Zussman 1998. "The Compliance Costs of Canada's Major Tax Systems and the Impact of Single Administration", Canadian Tax Journal, 46: 761-785.

Pitt, Mark, M. and Joel Slemrod, 1989. "The Compliance Cost of Itemizing Deductions: Evidence from Individual Tax Returns", American Economic Review, 79: 1224-1232.

Pope, Jeff 1993. "The Compliance Costs of Taxation in Australia and Tax Simplification: The Issues", Australian Journal of Management, 18: 6989.

, 1993a. "Policy Implications Arising from Compliance Costs of Taxation Research", Australian Tax Office (ATO) Conference, Canberra, November.

1994. "Compliance Costs of Taxation: Policy Implications", Australian Tax Forum, 11: 85-121.

1995. "Tax Compliance Costs of Major Taxes in Australia" in Cedric Sandford, (ed.), Tax Compliance Costs: Measurement and Policy. Bath, UK: Fiscal Publications.

Pope, Jeff, Richard Fayle, and M. Duncanson, 1990. " The Compliance Costs of Personal Income Taxation in Australia, 1986/87", Research Study No. 9. Australian Tax Research Foundation, Sydney, Australia.

Rajaraman, Indira 1995. "Presumptive Direct Taxation: Lessons from Experience in Developing Countries", Economic and Political Weekly, 30 May: 1103-1124.

Sandford, Cedric 1994. "Self Assessment For Income Tax: Another View", British Tax Review, 3: 674-680.

Sandford, Cedric 1994a. "International Comparisons of Administrative and Compliance Costs of Taxation". Australian Tax Forum, 11: 291-309.

Sandford, Cedric 1995. "Improving the Methodologies" in Cedric Sandford (ed.) Tax Compliance Costs Measurement and Policy. Bath, U.K: Fiscal Publications in association with The Institute for Fiscal Studies. 
Sandford, Cedric 1995. "The Rise and Rise of Tax Compliance Costs" in Cedric Sandford, (ed.) Tax Compliance Costs Measurement and Policy". Bath, U.K. Fiscal Publications in association with The Institute for Fiscal Studies.

Sandford, Cedric, Michael Godwin, and Peter Hardwick, 1989. Administrative and Compliance Costs of Taxation. Bath, UK: Fiscal Publications.

Slemrod, Joel 1995. "The Simplification Potential of Alternatives to Income Tax." Tax Note, 66 (27 February), 1331-1340.

Slemrod, Joel and John Bakija, 1996. 'Taxing Ourselves - Citizen's Guide to Great Debate Over Tax Reform'. London: MIT Press.

Slemrod, Joel and Nikki Sorum, 1984 "The Compliance Cost of the U.S. Individual Tax System" National Tax Journal, 37: 461-74.

Slemrod, Joel and Shlomo Yitzhaki, 1996. The Cost of Taxation and the Marginal Efficiency Cost of Funds, IMF Staff Papers, 43: 172-198.

Slemrod, Joel and Shlomo Yitzhaki, 1998. "Tax Avoidance, Evasion and Administration", Working paper, University of Michigan, Ann Arbor. Forthcoming in Alan Auerbach and Martin Feldstein (eds.) Handbook of Public Economics, Amsterdam: North Holland.

Smith, Adam 1976. An Enquiry Into the Nature and Causes of the Wealth of Nations, (see, e.g., New York, Modern Library, 1937).

Talib, Amin Ali 1996. "The Compliance Costs of Taxation", Bulletin for International Fiscal Documentation, 50. (September): 418-421.

Tan, L.M. and Tooley, S. 1994. "Tax Simplification: Progress to Date", Bulletin for International Fiscal Documentation, 48 (May): 236-38.

Tohamy, Sahar (1998): "Tax Administration and Transaction Costs in Egypt", Working Paper No. 33, Egyptian Centre for Economic Studies (ECES). 
Vaillancourt, Francois 1987. The Compliance Costs of Taxes on Business and Individuals: A Review of the Evidence, Public Finance, 395-414.

--- Personal Income Tax and Payroll Taxes", in Cedric Sandford (Editor), Tax Compliance Costs Measurement and Policy, Bath, U.K.: Fiscal Publications in association with The Institute for Fiscal Studies.

Vaillancourt, F. and Etienne Blais 1995. " The Evolution of Compliance Time of Personal Income Tax-filers in Canada 1971-93", in Cedric Sandford (ed.), Tax Compliance Costs Measurement and Policy. Bath, UK: Fiscal Publications in association with The Institute for Fiscal Studies.

Vaillancourt, Francois and Robert J. Reid, 1989. "National Report, Sweden", Studies in International Fiscal Law: Administrative and Compliance Costs of Taxation, Cahiers De Droit Fiscal International, Volume 74b. Rio De Janeiro: International Fiscal Association.

Walpole, Michael, et.al. 1999. "Taxation Compliance Costs: Some Lessons from "Down-under" British Tax Review, 4: 244-271. 